\title{
Study of High-tech Process Furnace using Inherently Safer Design Strategies (III) Advanced Thin Film Process and Reduction of Power Consumption Chih-Cheng Lu ${ }^{1}$, Kuo-Chi Chang ${ }^{1}$, Chun-Yu Chen*2
}

1 Institute of Mechanical and Electrical, Taipei University of Technology, Taipei 10608, Taiwan, ROC *2 College of Design, Vanung University, Tao-Yuan City 32061, Taiwan, ROC

\begin{abstract}
Semiconductor manufacturing is the economic backbone of Taiwan. Although efforts have been made to improve production capacity and achieve full load production, manufacturers are still unable to effectively control the power consumption situation during the failure of full load production due to special circumstances. Those processes do not conform to the characteristics of inherently safer design, which increases process risks. The objective of this research was to investigate the effects of power consumption reduction on the process furnace, maintaining the same production capacity in the existing 22nm advanced semiconductor process. In this study, TEOS was used as the raw material for LPCVD process simulation , experimentation, and exploration. The adopted LPCVD reactor was of the commercial batch type; the process experiments simulated the IPD process applied on the 22nm MOSFET, with a thickness of 5000 and process time of $60 \mathrm{~min}$. The simulation results of different batches were compared with the experimental values, and the simulation values were consistent with the experimental values by adjusting the different ka values. The reactor contained processes for 125 wafers and 100 wafers. According to the simulation and experimental results, the thin film deposition results were acceptable. Finally, the heating zone output current was explored specifically for two batches of wafers in the 12" furnace tube process. In the process of the first batch, as there were only 100 wafers, 18.05A was reduced by shutting off the 5th heating zone. The machine had a voltage of $220 \mathrm{~V}$ and converted power output up to $3971 \mathrm{~W}$, accounting for $26 \%(15265.8 \mathrm{~W})$ of the entire machine. This significantly reduced power supply of the entire machine and hazard potential, which is consistent with the characteristics of inherently safer design. Moreover, there were fifteen 12" tube furnace machines in the experimental workshop of this study, and shutting off unnecessary heating zones could reduce 59565W/H of the power supply and hazard potential. Finally, the 12 " tube film process machine electrical hazards and damage control measures were analyzed by using FMEA method, and confirmed that the research results were in line with the expected attenuation strategy of ISD. This approach has increased the safety level, but also reduced operating costs, which is an important achievement of this study.
\end{abstract}

世Keywords丕 Inherently Safer Design, LPCVD, Thin Film deposition, 22nm IC process, Reduction of Power Consumption, FMEA. 


\section{List of the Acronyms}

1. STI: Shallow Trench Isolation

2. TEOS, Si $\left(\mathrm{OC}_{2} \mathrm{H}_{5}\right)_{4}$ : Tetraethyl Orthosilicate

3. IPD: Inter-Poly Dielectric

4. MOSFET: Metal-Oxide-Semiconductor Field-Effect Transistor

5. LPCVD: Low Pressure Chemical Vapor Deposition

6. CD: critical dimensions

7. ILD: Inter Layer Dielectric

8. PMD: Pre-Metal Dielectric

9. IMD: Isolation Metal Dielectric

10. T: temperature

11. MF: mole fraction

12. F: flow rate

13. P: pressure

14. PR: Photo Resist

15. FMEA: Failure Mode and Effects Analysis

16. $\circ$ : Experiment result

17. $\Delta$ : modified result

\section{Introduction}

Semiconductor manufacturing is the economic backbone of Taiwan. Although efforts have been made to improve production capacity and achieve full load production, manufacturers still cannot effectively control the power consumption situation during the failure of full load production due to special circumstances. This increases the process risks and fails to meet the spirit of inherently safer design. Under the influence of the global financial crisis of 2008, Taiwan's semiconductor manufacturers have significantly reduced production capacity. Consequently, in the processing of numerous batches, while only a part of the pieces can be put into production, all process parameters are enabled. Taking LPCVD for example (as shown in Figure 1), the 12"furnace tube machine is the batch process and the number of wafers in each batch process is 150 . If the production capacity utilization rate is $70 \%$, then 105 wafers are put into production in each batch; however, the process parameters of the process machine of each batch must be comprehensively considered, as the enterprises are unable to effectively develop the process parameter control scheme. Regarding thin film deposition, temperature is an important process control parameter. Some studies have estimated the simulation results of the influence on process temperature distribution by shutting off heating zones (Chen et al., 2013a).

For the LPCVD process, the main process parameters include T, MF, F, and P. Among the parameters, temperature has the most affect on the thin film deposition rate, thus, it is the most important process parameter (Chen et al., 2013b); however, most current 12” LPCVD vertical furnace tube machines are 
designed with five heating zones, as shown in Figure 1. In the timing sequence of temperature control, the temperature of the furnace tube heating zone is first improved and transferred to the center of the furnace tube, thereby enabling wafer temperature to rise. When the temperature and heating time reach the set values, the reaction gas would be introduced into the reactor of the furnace tube for reaction, as shown in Figure 2 (Harbeke et al., 1984). However, for process stability, most manufacturers do not make any changes after the temperature control is set, regardless of the number of wafers put into the process, even when an excessive power supply would result in additional and unnecessary risks. This does not meet the concept of inherently safer design (Khan and Amyotte, 2004; Kletz and Amyotte, 2012; Chen et al., 2014).

In the current 22nm advanced semiconductor process, although no significant changes are made in the element principle, various new research findings are added to actual commercial production in order to seek the gradual reduction of Critical Dimension (CD). As shown in Figure 3, in the current 22nm advanced semiconductor process product structure, the main process changes are those made based on product structure changes, including the STI production of elements (Sze and Ng, 2006), production regarding the heavy doping of $\mathrm{SiC}$ and SiGe to change the structural pull stress layer or compress stress layer (Biela et al., 2011; Avenier et al., 2009), the structural design regarding gate width reduction, the process application of high-K materials (Gusev et al., 2001), and the application of self-aligned structures (Stutzmann et al., 2003; Liao et al., 2010). The integration design of element processes and analysis of safety and health management issues are summarized in Table 1.

The equipment structure can be modified specific to advanced 22nm process changes, as based on process requirements; thereby affecting the potential hazards of the process machine (Zhou., 2010). Therefore, this study conducted analysis hazards in advanced 22nm IC process, equipment, and facility system, and the results are shown in Table 2. As seen, high-temperature, gas leaks, fires, explosions, shocks, rolling and crimping, organic solvent poisoning, acid and alkali corrosion, hitting, and cutting are hazardous items that require particular attention in the advanced semiconductor process. Since the process determines the structure and function of the machine and equipment, from a safety point of view, the safety level could be inherently changed if changes are made in the process to render workshop operations safer.

Temperature control purpose is to meet the needs for the successful completion of process requirements. So this study began to explore a thin-film process using 12 " furnace to analyze the temperature control to meet the expected process conditions, and then established an effective control mechanism to allow the temperature power consumption, which could be reduced in order to reach the essence of inherently safer design (ISD) strategies. Concepts and mechanism analysis of this study could be used for the safety and health management staff in various similar machines. It is the important contribution of this study, including with the effectiveness of both safety and operation cost down.

\section{Methodology}

This study started from 12 " furnace to achieve advanced 22nm thin-film process, then the process requirements could be satisfied by using the further analysis of temperature control, and finally applied the ISD strategies to discuss energy consumption. 
Although many changes have been made in the advanced 22nm IC process, the deposition of SiO2 remains an important process for most products, and is adopted by STI, ILD layer, Sidewall Spacer layer, PMD layer, and IMD layer, and continued exploration of such processes is necessary (Faccio et al., 2008). Chen et al. (2013a) (2013b) applied the method proposed by He et al. (2003) onto the horizontal LPCVD reactor of the 6" wafer process, and used the thermal radiation configuration factor to correct the practice of Badgwell et al. (1994), in order to establish a set of steady-state linear relationships of the furnace tube and wafer temperatures. They also adopted the method proposed by Kim and Kim (1999) to study and simulate the temperature distribution model and process effects. The reaction mechanism, as mentioned by Jensen and Graves (1983), was used to establish the deposited film thickness model, and conduct simulation and verification using SiH4 to deposit Poly-Si. Table 3 shows the CVD thin film materials used in the semiconductor summarized in this study. Table 4 shows the CVD related materials and deposition methods (Sze and Ng, 2006).

In this study, Tetraethyl Orthosilicate (TEOS, Si (OC2H5) 4) was used as the raw material. TEOS is an organic molecule that has high surface mobility. CVD thin film deposition, as based on TEOS. It generally has good step coverage and trench filling ability, and is widely used in the deposition of oxide, including STI, sidewall spacer, PMD, and IMD. TEOS is in the liquid state at room temperature and atmospheric pressure. During application, heating the TEOS container (about 40 70乃) increases its saturated vapor pressure for the convenience of application in the gas state. As TEOS has a very high boiling point (about 169 at atmospheric pressure), in the CVD process application and under high temperature, TEOS can only have the reaction of Eq. (1) due to its need for adequate heat in order to further generate the $\mathrm{SiO} 2$ resultant. As a result, the furnace tube is commonly used for this process. Eq. (1) uses the reaction formula of TEOS generating SiO2 (Desu et al., 1989; Huang et al., 2003).

$$
\mathrm{Si}\left(\mathrm{C}_{2} \mathrm{H}_{5} \mathrm{O}\right)_{4(g)} \longrightarrow \mathrm{SiO}_{2(s)}+4 \mathrm{C}_{2} \mathrm{H}_{4(g)}+2 \mathrm{H}_{2} \mathrm{O}_{(g)}
$$

From Eq. (1) and Desu et al. (1989), the reaction kinetics for $\mathrm{SiO}_{2}$ were shown in Eq. (2), (3), and (4):

1. TEOS decomposition in gas phase:

$$
\mathrm{Si}\left(\mathrm{C}_{2} \mathrm{H}_{5} \mathrm{O}\right)_{4} \text { 日奇埇 } \mathrm{I}+\mathrm{R}_{1}
$$

2. Adsorption reaction:

$$
I \text { 日苜畘 } I^{*}
$$

3. Surface chemical reaction:

$$
I^{*} \stackrel{k_{d}}{\longrightarrow} \mathrm{SiO}_{2}+R_{2}+*
$$

The deposition reaction rate: 


$$
r=\frac{k_{d} K_{a}\left(K_{g} C\right)^{0.5}}{1+K_{a}\left(K_{g} C\right)^{0.5}}\left(\frac{\text { mole }}{\mathrm{cm}^{2} \cdot \mathrm{s}}\right)
$$

where

r: deposition reaction rate $\left(\frac{\text { mole }}{\mathrm{cm}^{2} \cdot s}\right)$

C: TEOS gas concentration $\left(\frac{\text { mole }}{\mathrm{cm}^{3}}\right)$

R: gas constant

$\mathrm{T}$ : reaction temperature $(\mathrm{K})$

$K_{g}=1.38 \times 10^{4} \exp (-299240 / 8.314 T)\left(\frac{\mathrm{mol}}{\mathrm{cm}^{3}}\right)$

$K_{a}=1.14 \times 10^{10} \exp (-21422 / 8.314 T)\left(\frac{\mathrm{cm}^{3}}{\mathrm{~mol}}\right)$

$k_{d}=4.74 \times 10^{-8} \exp (-12259 / 8.314 T)\left(\frac{\mathrm{mol}}{\mathrm{cm}^{2} \cdot \mathrm{s}}\right)$

The assumed conditions of this study are as follows:

1. 1-D mode.

2. The thin film deposition of the isotropic phase is uniform.

3. The reaction occurs only on the effective area.

4. Isotropic thin film deposition.

5. The temperatures of wafers are uniform.

6. TEOS is plug flow.

7. The trench reaction deposition is not considered.

The LPCVD reactor adopted in this study was of the commercial batch type (ASM a412); 148 chips could be put in the reactor each time, including 125 pieces of wafers, 20 pieces of blank pieces, and 3 pieces of test pieces. The 3 test pieces were No. 14, 70, and 134, which are counted from the bottom of the LPCVD reactor. After each process was completed, the thickness of the thin film on these three test pieces was 
measured, which was not performed on other wafers to obtain the wafer thickness at these 3 locations. The wafer used in the process was 12 inches $(300 \mathrm{~mm})$ and operated under 0.6 torr pressure. The reactor had a diameter of $435 \mathrm{~mm}$ and a length of $1215 \mathrm{~mm}$. The rotation speed of the cassette was $2 \mathrm{rpm}$; and the feed flow rate of TEOS was $380 \mathrm{sccm}$. The process experiments simulated the IPD process applied on the 22nm MOSFETs, with a thickness of $5000 \AA$ and process time of 60 minutes. The status data within the LPCVD reactor of this study are as shown in Table 5.

In this study, process capacity comparison was conducted through simulation and actual testing in order to confirm that the process capacity is able to maintain the desired target in the case of process parameter changes. As temperature is the most important process parameter of thin film deposition, this study focused on adjustment of the $5^{\text {th }}$ heating zone of the 12 " furnace tube under the condition that other factors, such as the $\mathrm{mf}, \mathrm{F}$, and $\mathrm{P}$, remain unchanged.

Based on the thin film deposition processes of different process wafer numbers, it is important to grasp temperature control for decreased number of wafers, in order to reduce the input power of the machine and equipment. This can satisfy the attenuation design strategy in an inherently safer design, which can reduce the hazard of machine and equipment. The monitoring method of the temperatures of the five heating zones of the machine in this study is as shown in Figure 4. The temperature monitoring started from the element control panel, as its power was supplied to the power supply unit, which can control the power of each heating zone through the thyristor (as shown in Figure 5). Figure 6 shows the condition when only 60\% power was input to a heating zone. The temperature control circuit of the experimental and test machine in this study is as shown in Figure 7 (ASM, 2013).

As regards the ISD strategy of attenuation, when the process piece number began to decrease from the full load, under the condition that the requirements of the desired process target could still be maintained, reducing the power input of heating zone could significantly reduce the power hazard, as well as other unnecessary hazards.

In the main framework of this study, the use of FMEA analysis was applied to the 12 "tube film process machine electrical hazards and damage control measures. Comparisons and discussion on the final analysis with those of the results of major research were made to double confirm the research outcome, which is consistent with the expectation in weakness of ISD strategy.

\section{Film deposition process simulation and experiment}

Without considering the chip trench area, the simulation, experimentation, and comparison were conducted based on the assumption that the pieces in a group of LPCVD reactor of 12" furnace tube are all blank pieces. The kg, ka, and kd values were from literature, as shown in Eq. (9). Regression analysis was conducted through the simulation, experimentation, and comparison of blank pieces. The results are the values shown in Eq. (10), which are used for subsequent experimentation and discussion (Desu et al.,1989; Huang et al., 2003). 


$$
\begin{aligned}
& \left\{\begin{array}{l}
K_{g}=1.38 \times 10^{4} \exp (-299240 / 8.314 T) \\
K_{a}=1.14 \times 10^{10} \exp (-21422 / 8.314 T) \\
k_{d}=4.74 \times 10^{-8} \exp (-12259 / 8.314 T)
\end{array}\right. \\
& \left\{\begin{array}{l}
K_{g}=1.38 \times 10^{4} \exp (-299240 / 8.314 T \\
K_{a}=1.14 \times 10^{10} \exp (-21422 / 8.314 T \\
k_{d}=3.5370^{-8} \exp (-11700 / 8.314 T
\end{array}\right)
\end{aligned}
$$

Figure 8 shows the results after regression. A comparison was made between the thicknesses of the 5 blank wafers measured in the field. The results were obtained through simulation of the established physical model. Regression of the reaction kinetics formula of the deposition reaction was then conducted. Eq. (9) is the reaction kinetics formula, based on previous literature. The reaction kinetics formula of Eq. (10) can be obtained after regression is conducted. According to a comparison of Eqs. (9) and (10), only the $K_{d}$ value presents some small differences in the data after regression. In Figure 8, the red dot denotes the field-measured data, while the black line denotes the result of simulation. The simulation result and experimental data are consistent. From the diagram of the TEOS reaction rate and temperature in Figure 9, the symbols: $\circ$ (Experiment) $\Delta$ (modified). The difference is very little, suggesting that there is little change in the reaction kinetics formula through regression and the reaction kinetics formula of literature.

In this study, simulation and experiments were conducted at the TESO feed flow rate of 380sccm. The TESO feed flow rate could be divided into two types, 380sccm and $230 \mathrm{sccm}$. The wafer number inside the reactor could be divided into 125 wafers and 100 wafers after reduction, respectively. Simulation with the data of the TESO feed flow rate of 380sccm was conducted first. If the memory size of the chip cut from the wafer were $256 \mathrm{MB}$, the trench area of the wafer must be considered when calculating the reaction area. Figures 10 and 11 show the comparison of the simulation results and experimental values of different batches. The simulation values and experimental values were made consistent with each other by adjusting the different ka values. The reactor contained the processes for 125 wafers and 100 wafers. The difference between Figures 10 and 11 revealed that the reaction area after piece No. 110 was very small, as shown in Figure 10, as only blank wafers were placed after it. In Figure 11, as it is fully filled with 125 wafers, the blank wafers only appeared after piece No. 131. According to the simulation and experimental results in Figures 10 and 11, the thin film deposition results were acceptable. Figure 12 shows the SEM results after thin film deposition and thickness confirmation by etching. In order to clearly see the deposited film thickness, wet etching was performed after the surface was applied with PR, thus, the IPD thickness after the deposition reaches $5009 \AA$ met the process requirements.

\section{Discussion of power hazard elimination and control on ISD strategies and FMEA analysis}

The hazard of the most concerned in the thin film deposition process is the power hazard; therefore, temperature control in the process is very important. Especially in the case of a reduction in the number of 
pieces in the process, the effective power input reduction is bound to significantly improve the inherently safer level of the process machine. Most studies on power supply discuss the economic subjects, such as energy consumption saving (Shnayder et al., 2004; Carroll, 2010; Kirousis et al., 2000), but there lacks discussion on safety, such as the power hazard. There are scanty studies on the dispatching safety of system energy consumption (Kocher et al., 1999). Therefore, it is necessary to explore the power hazard from the point of view of ISD. The detailed temperature change conditions specific to the process machine selected in this study were explored. The temperature changes of a single heating zone are as shown in Figure 13. As seen, the thermometer captured the temperature value once per second, and the average power input was adjusted every $2 \mathrm{~min}$. Thus, when the temperature was set to 700 乃, the power input was effectively controlled within the range of \pm 0.5 乃, meaning the process temperature is able to meet the desired target.

In this study, the heating zone output current is explored specific to the aforementioned two batches of wafers in the 12" furnace tube process, with the results as shown in Tables 6 and 7 . In the process of the first batch (Table 6), as there are only 100 wafers, the $5^{\text {th }}$ heating zone is shut off and the discussed desired process target is attained. Therefore, $18.05 \mathrm{~A}$ can be reduced by shutting off the $5^{\text {th }}$ heating zone. The machine had a voltage of $220 \mathrm{~V}$ and converted power output up to $3971 \mathrm{~W}$, accounting for $26 \%$ (15265.8W) of the entire machine, indicating significantly reduced power supply of the entire machine and hazard potential. This is consistent with the characteristics of inherently safer design. Moreover, there were fifteen 12 "furnace tube machines in the experimental workshop of this study, and shutting off unnecessary heating zones could reduce 59565W/H of the power supply, thus, lessening the hazard potential.

In Taiwan, due to the limited workshop layout area, the process machines are densely arranged, resulting in a very high combustible density per unit area. Moreover, a large number of supply lines are arranged closely in the clean room and auxiliary clean room according to the process needs. Although the temperature abnormalities resulted from a loose connection and insulation deterioration could be discovered by infrared detection during safety patrol inspections of the machines and equipment at the ordinary times (as shown in Figure 14) ( Lin, 2002; Chen et al.,2013), many electrical circuits are hidden in the depths of the machines and equipment, constituting continued difficulties in safety management. Regarding the electric power system, the inherently safer strategy of shutting down heating zones should be implemented in the case of production reduction in process planning in order to reduce the power supply and further reduce the combustion of heating zone contacts (as shown in Figure 15). In this study, the current process temperature supply and control system for commercial operation machine of accident statistics (please refer Figure 4 of the temperature control framework), found that the heating zones element contacts most often occurred due to not lock to the proper torque that caused by the ohm contact is too large and would caused overheating short circuit explosion, as show in Figure 15 of (c) photos. Therefore, if in the process reduction of production, properly closing the no effect of the process of heating zones will effectively reduce the operating current of the heating element. The contacting heat could also be reduced simultaneously, and the more inherently safer level would be increased dramatically.

In order to ensure compliance with the preceding main results of risk assessment, FMEA methods were applied to 12 " tube machine temperature control system for analysis in this study, the results as shown in Table 8. From the experimental results showed that Heating elements No. 1 to 5 were as the most 
prone to failure and after the failure of the most serious damage. If more deeply explored the reasons, because of insufficient torque fixed terminals when the heating element was installed, resulting in ohmic contact resistance was too large, further leading to the contact heat, and finally contacts burning or explosion. In lighter condition, would impact on the process shutdown and warning light action; in severe condition, cause the smoke early detectors warning system action, and then withdraw the whole plant, or contacts explosion cause a high-tech factory fire. Therefore, if in the production process, the effective closure of the unnecessary heating zone, the overall process tool operating current decreases. These satisfied the attenuation strategy of ISD, eliminating the risk of the aforementioned short-circuit and contact point explosion, and improving the overall plant safety. This argument was fully consistent with those of the impact and consequences in Figure 15 of (c) photos.

From the foregoing discussion, some important suggestions on the LPCVD process should have the following practices:

(1) In the request to maintain the process, maximizing the use of non-combustible liquid or chemicals to reduce the overall machine fire and explosion possibilities.

(2) In the process of full load, the anomalous temperature monitoring device of heating control loop should be implemented and timely linkage to interrupt the process while occurring the chain reaction could be reduced.

(3) In the manufacturing process was not fully loaded, the machine heating control loop could automatically turn off the non-heating zone heater function, reducing the overall machine power usage, and then eliminating the risk of fire and explosion from the heating sources.

(4) The machine exhaust system of non-manufacturing process should be readily linked process heating systems. When the failure in exhaust system led to the external environment flammable gases entering the interior of furnace tube machine, process heating system should be able to automatically turn off the heating function, and then the heat sources of fire and explosion could be eliminated.

\section{Conclusions}

The current process changes of the 22nm advanced semiconductor include the STI production of elements, production regarding the heavy doping of $\mathrm{SiC}$ and SiGe to change the structural pull stress layer or compress stress layer, the structural design regarding gate width reduction, the process application of high-K material, the application of self-aligned structures, and the integration design of element processes. In addition, high-temperatures, gas leaks, fires, explosions, shocks, rolling and crimping, organic solvent poisoning, acid and alkali corrosion, hitting, and cutting are the hazardous items that require particular attention in advanced semiconductor processes.

Although many changes have been made in advanced semiconductor processes, the deposition of $\mathrm{SiO} 2$ remains an important process for most products, and is adopted by the STI, ILD layer, Sidewall Spacer layer, PMD layer, and IMD layer. Continued exploration of the process remains necessary. In this study, TEOS 
was used as the raw material for LPCVD process simulation, experimentation, and exploration. The LPCVD reactor adopted in this study was of the commercial batch type (ASM a412); 148 chips were put in the reactor each time, including 125 pieces of wafers, 20 pieces of blank pieces, and 3 pieces of test pieces. The 3 test pieces were No. 14, 70, and 134, which were counted from the bottom of the LPCVD reactor. The wafer used in the process was 12 inches $(300 \mathrm{~mm})$ and operated under 0.6 torr pressure. The reactor had a diameter of $435 \mathrm{~mm}$ and a length of $1215 \mathrm{~mm}$. The rotation speed of the cassette was 2rpm, and the feed flow rate of TEOS was $380 \mathrm{sccm}$. The process experiments simulated the IPD process applied on the 22nm MOSFETs, with a thickness of $5000 \AA$ and process time of $60 \mathrm{~min}$. The simulation results of different batches were compared with the experimental values, and the simulation values were consistent with the experimental values by adjusting the different ka values. The reactor contained the processes for 125 wafers and 100 wafers. According to the simulation and experimental results, the thin film deposition results are acceptable.

The heating zone output current was explored specific to two batches of wafers in the 12" furnace tube process. In the process of the first batch, as there were only 100 wafers, the $5^{\text {th }}$ heating zone was shut off, and $18.05 \mathrm{~A}$ was reduced. The machine had a voltage of $220 \mathrm{~V}$, and a converted power output up to $3971 \mathrm{~W}$, accounting for $26 \%$ (15265.8W) of the entire machine. The power supply of both the machine and hazard potential was significantly reduced, which is consistent with the characteristics of an inherently safer design. Moreover, there were fifteen 12"furnace tube machines in the experimental workshop of this study, and shutting off unnecessary heating zones could reduce $59565 \mathrm{~W} / \mathrm{H}$ of power supply, thus, reducing the hazard potential. Finally, the 12 " tube film process machine electrical hazards and damage control measures were analyzed by using FMEA method, and confirmed that the research results were in line with the expected attenuation strategy of ISD.

In Taiwan, due to the limited workshop layout area, the process machines are densely arranged. In addition to infrared detection during the safety patrol inspection of the machines and equipment at ordinary times, for the electric power system, the inherently safer strategy of shutting of the heating zones is implemented for production reduction during process planning in order to reduce the power supply, and further reduce the combustion of heating zone contacts. Based on the chemical process safety management architecture, as proposed by Hendershot (1997), it is found that inherently safer design strategies, such as the intensification, substitution, attenuation, and limitation of effects, could be applied specifically to the process design, in order to fundamentally eliminate the hazard potentials and significantly increase the overall safety level of the workshop (as shown in Figure 16).

\section{Acknowledgement}

Funding for this investigation was provided by National Science Foundation, Taiwan, ROC. Under grant number NSC102-2622-E-238-008-CC3.

\section{References}

1. ASM Company. (2013). a412 Installation manual. 
2. Avenier, G., Diop, M., Chevalier, P., Troillard, G., Loubet, N., Bouvier, J., Depoyan, L., Derrier, N., Buczko, M., Leyris, C., Boret, S., Montusclat, S., Margain, A., Pruvost, S., Nicolson, S.T., Yau, K.H.K.,

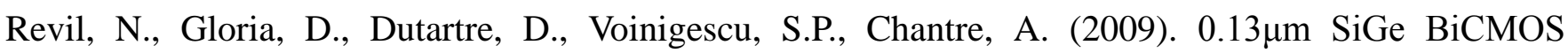
Technology Fully Dedicated to mm-Wave Applications. IEEE Journal of Solid-State Circuits, 44(9), $2312-2321$.

3. Badgwell, T. A., Trachtenberg, I., \& Edgar, T. F. (1994). Modeling the wafer temperature profile in a multiwafer LPCVD furnace. Journal of the Electrochemical Society,141, 161-172.

4. Biela, J., Schweizer, M., Waffler, S., Kolar, J.W. (2011). SiC versus Si-Evaluation of Potentials for Performance Improvement of Inverter and DC-DC Converter Systems by SiC Power Semiconductors. IEEE Transactions on Industrial Electronics, 58(7), 2872 - 2882.

5. Carroll, A., \& Heiser, G. (2010). An analysis of power consumption in a smartphone. Paper presented at the Proceedings of the 2010 USENIX conference on USENIX annual technical conference.

6. Chen, C.Y., Chang, K.C., Wang, G.Bin. (2013a). Study of High-tech Process Furnace using Inherently Safer Design Strategies (I) Temperature Distribution Model and Process Effect. Journal of Loss Prevention in the Process Industries, 26(6), 1198-1211.

7. Chen, C.Y., Chang, K.C., Lu, C.C., Wang, G.B. (2013b). Study of high-tech process furnace using inherently safer design strategies (II) Deposited film thickness model. Journal of Loss Prevention in the Process Industries, 26, 225-235.

8. Chen, C.Y., Chang, K.C., Huang, C.H., Lu, C.C. (2014). Study of chemical supply system of high-tech process using inherently safer design strategies in Taiwan. Journal of Loss Prevention in the Process Industries, 29 , 72-84.

9. Chen, S.L., Lu, P.T., Lee, H.L., Lu, C.H., Yuan, S.Y., Tsai, H.Y., Chen, J.R. (2013). Risk Management and Regulatory Control of Toxic Chemicals in Taiwan. Journal of CHEMICAL ENGINEERING TRANSACTIONS, 31, 537-542.

10.Desu, S. B. (1989). Decomposition chemistry of Tetraethoxysilane. Journal of the American Ceramic Society, 72(9), 1615.

11.Federico, F., Hugh, J.B., Xiao, J., Chen, D.M., Fleetwood, Gonella, L., McLain, M., Schrimpf, R.D. (2008). Total ionizing dose effects in shallow trench isolation oxides. Journal of Microelectronics Reliability, 48(7), 1000-1007.

12.Harbeke, G., Krausbauer, L., Steigmeier , E.F., Widmer, A.E., Kappert, H.F., Neugebauer, G. (1984). Growth and Physical Properties of LPCVD Polycrystalline Silicon Films. Journal of the electrochemical society, 131(3), 675-682.

13.He, Q., Qin, S. J., \& Anthony, J. T. (2003). Computationally efficient modeling of wafer temperatures in a low-pressure chemical vapor deposition furnace. IEEE Transactions on Semiconductor Manufacturing, 16, 342-350. 
14. Hendershot, D.C. (1997). Safety through Design in The Chemical Process Industry: Inherently Safer Process Design. Benchmarks for World Class Safety through Design Symposium.

15.Huang, H.P., Jeng, J.C., Chiang, C.H., Pan, W. (2003). A direct method for multi-loop PI/PID controller design. Journal of Process Control, 13(8), 769-786.

16. Jensen, K. F., \& Graves, D. B. (1983). Modeling and analysis of low pressure CVD reactors. Journal of the Electrochemical Society, 130, 1950-1957.

17. Khakzad, N., Khakzad, S., Khan, F. (2014). Probabilistic risk assessment of major accidents: application to offshore blowouts in the Gulf of Mexico. Journal of Natural Hazards, 74(3), 1759-1771.

18.Khan, F. I., \& Amyotte, P. (2004). Integrated inherent safety index (I2SI): a tool for inherent safety evaluation. Journal of Process Safety Progress, 23(2), 136-148.

19.Kim, I. K., \& Kim, W. S. (1999). Theoretical analysis of wafer temperature dynamics in a low pressure chemical vapor deposition reactor. International Journal of Heat and Mass Transfer, 42, 4131-4142.

20.Kirousis, L.M., Kranakis, E., Krizanc, D., Pelc, A. (2000). Power consumption in packet radio networks. Journal of Theoretical Computer Science, 243(1-2), 289-305.

21.Kletz, T. A. \& Amyotte, P (2012). Process Plants: A Handbook for Inherently Safer Design, Second Edition. Taylor \& Francis.

22.Kocher, P., Jaffe, J. and Jun, B. (1999). Differential power analysis, Proceedings of Advances in Cryptology, 388-397.

23.Liao, L., Lin, Y.C., Bao, M.Q., Cheng, R., Bai, J.W., Liu, Y., Qu, Y.Q., Wang, K.L., Huang, Y., Duan, X.F. (2010). High-speed graphene transistors with a self-aligned nanowire gate. Journal of Nature, 467, 305-308.

24.Lin, Y.C., Yang, C. (2002). Risk assessment in safety management of the semiconductor industry in Taiwan. Journal of Risk Assessment and Management, 3(2-4), 222-233.

25.Shnayder, V., Hempstead, M., Chen, B., Werner, G.A., Welsh, M. (2004). Simulating the power consumption of large-scale sensor network applications, International Conference on Embedded Networked Sensor Systems, 188-200.

26.Stutzmann, N., Friend, R.H., Sirringhaus, H. (2003). Self-Aligned, Vertical-Channel, Polymer Field-Effect Transistors. Journal of Science, 299(5614), 1881-1884.

27.Sze, S. M., \& Ng, K. K. (2006). Physics of semiconductor devices (3rd ed.). Wiley, ISBN 978-0-471-14323-9.

28. Zhou, J.F. (2010). SPA-fuzzy method based real-time risk assessment for major hazard installations storing flammable gas. Journal of Safety Science, 48(6), 819-822. 

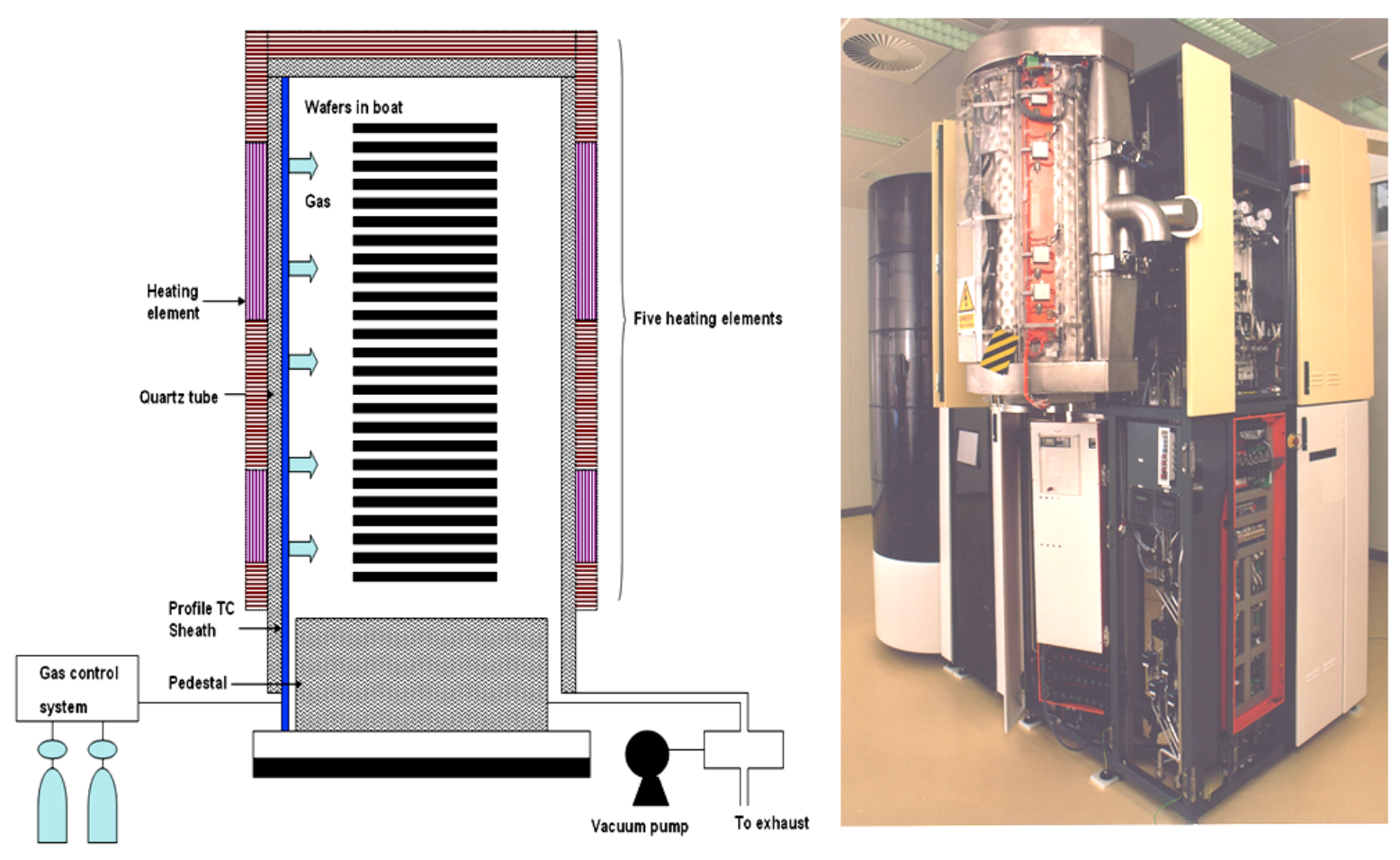

(a)Structure of 12 "LPCVDfurnacetool (b)Commercialized12 "LPCVD furnacetool settings

Figure 1 The High-Tech process machine of 12 "LPCVDfurnace

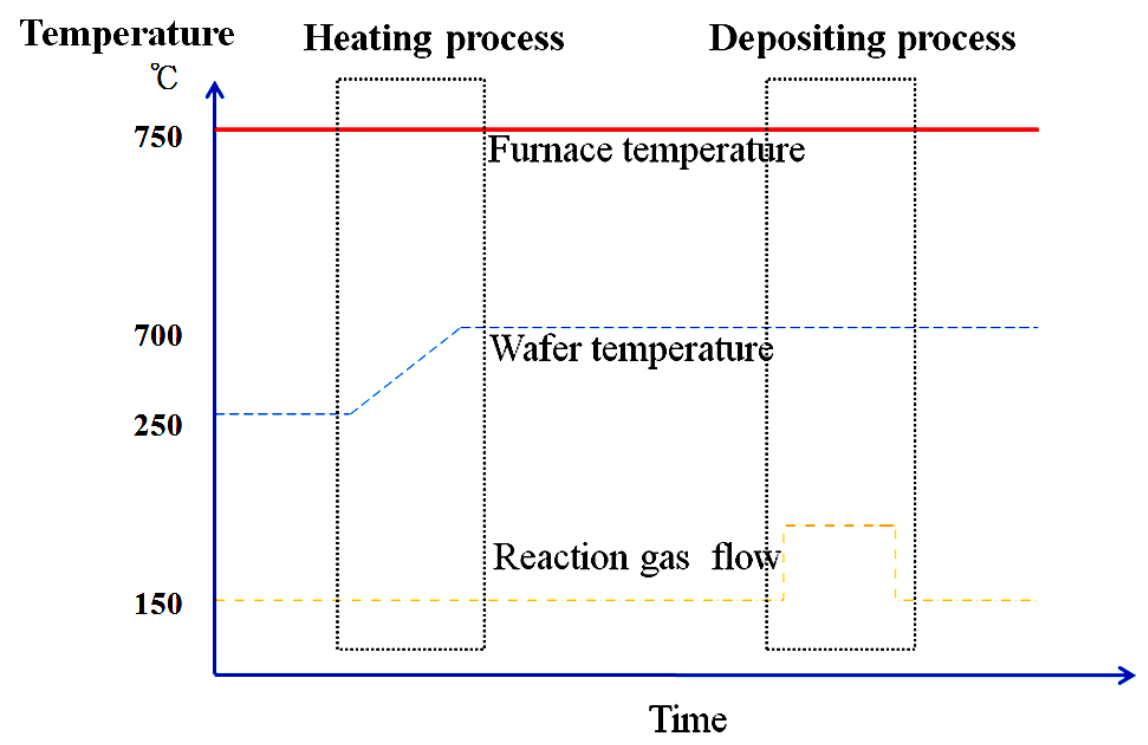

Figure 2 Timing Diagram of heating and depositing process of furnace, wafer, and reaction gas 


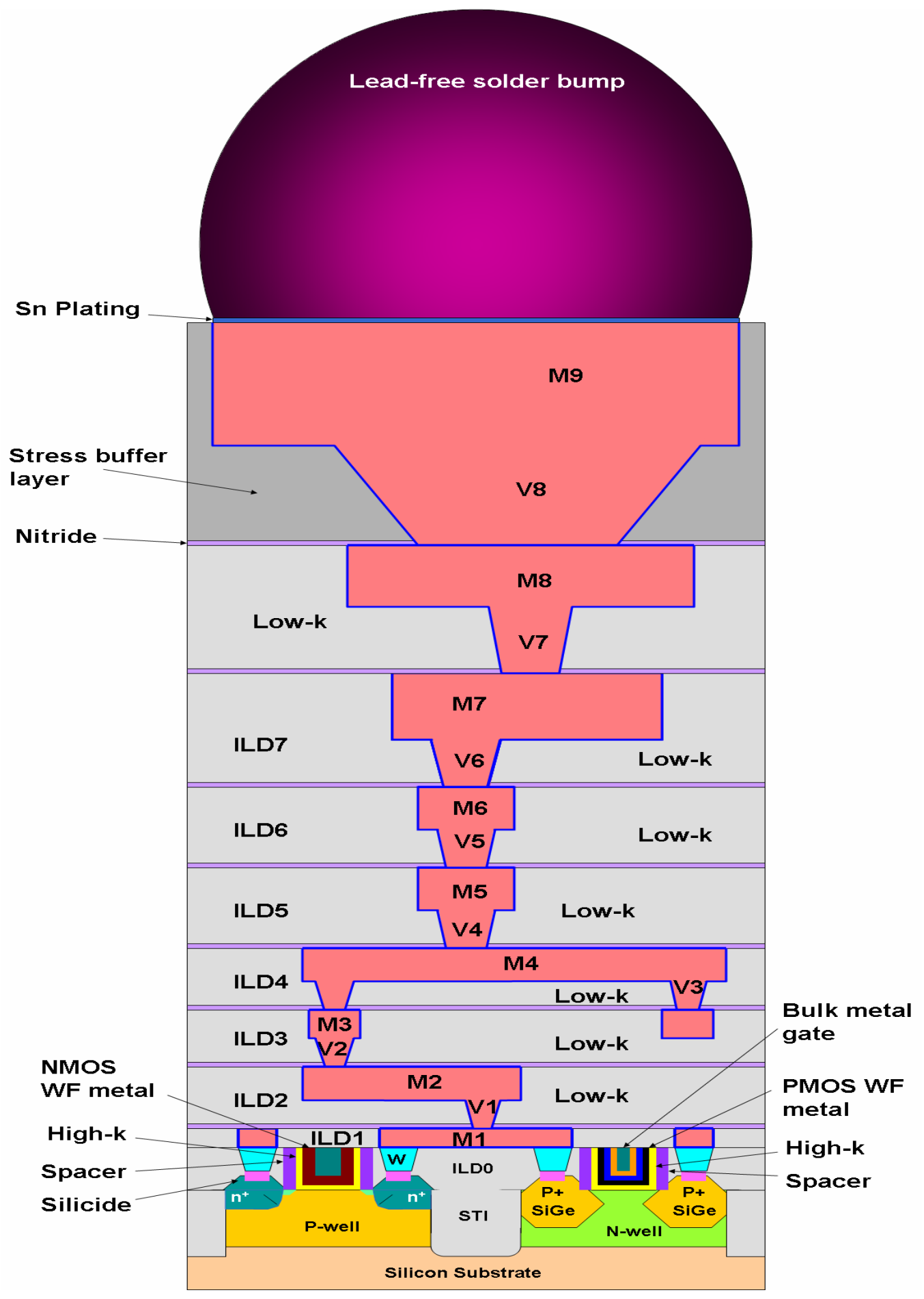

Figure 3 Advanced LogicProduct Architecture of 22nm IC 


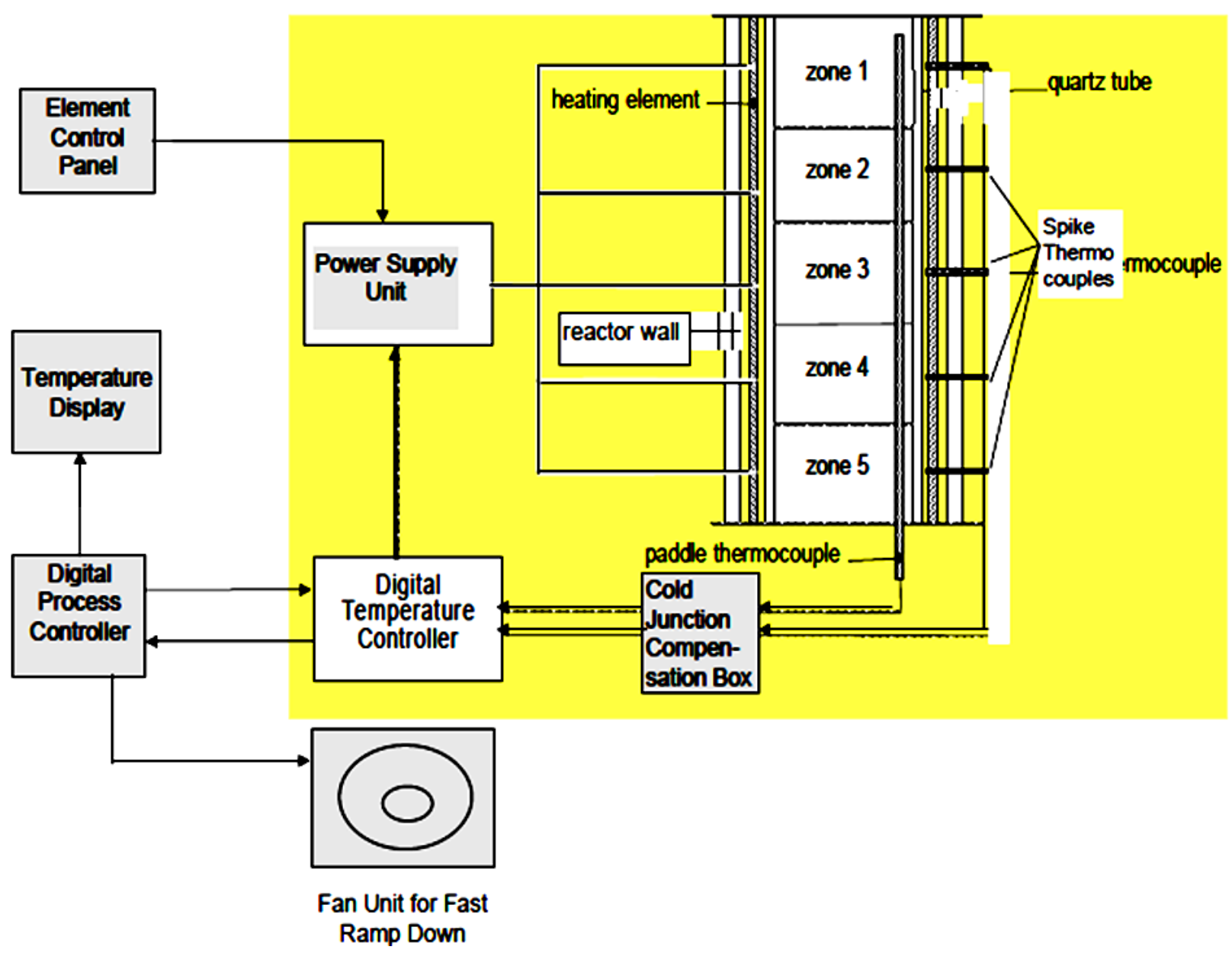

Figure 4temperaturecontrol framework of LPCVD five heating zones

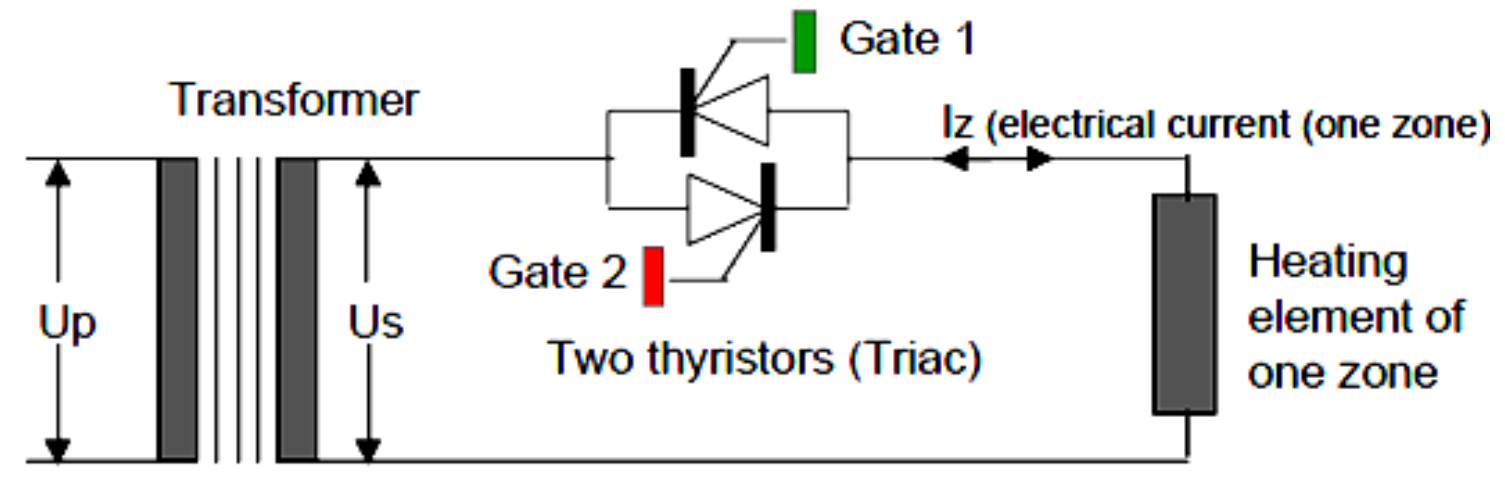

Figure 5SCR (Silicon Controlled Rectifiers) powercontrol architecture of powersupply for heating zone 


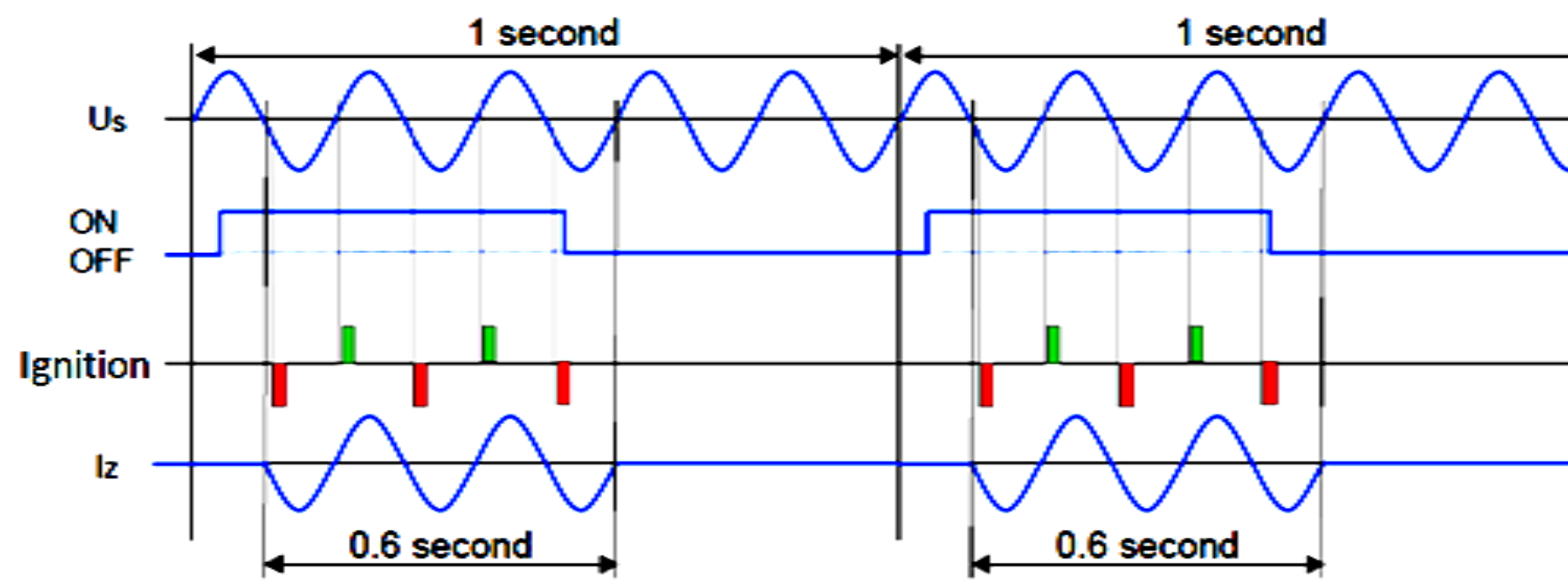

Figure 6SCR powercontrol at input60\% power Consumption

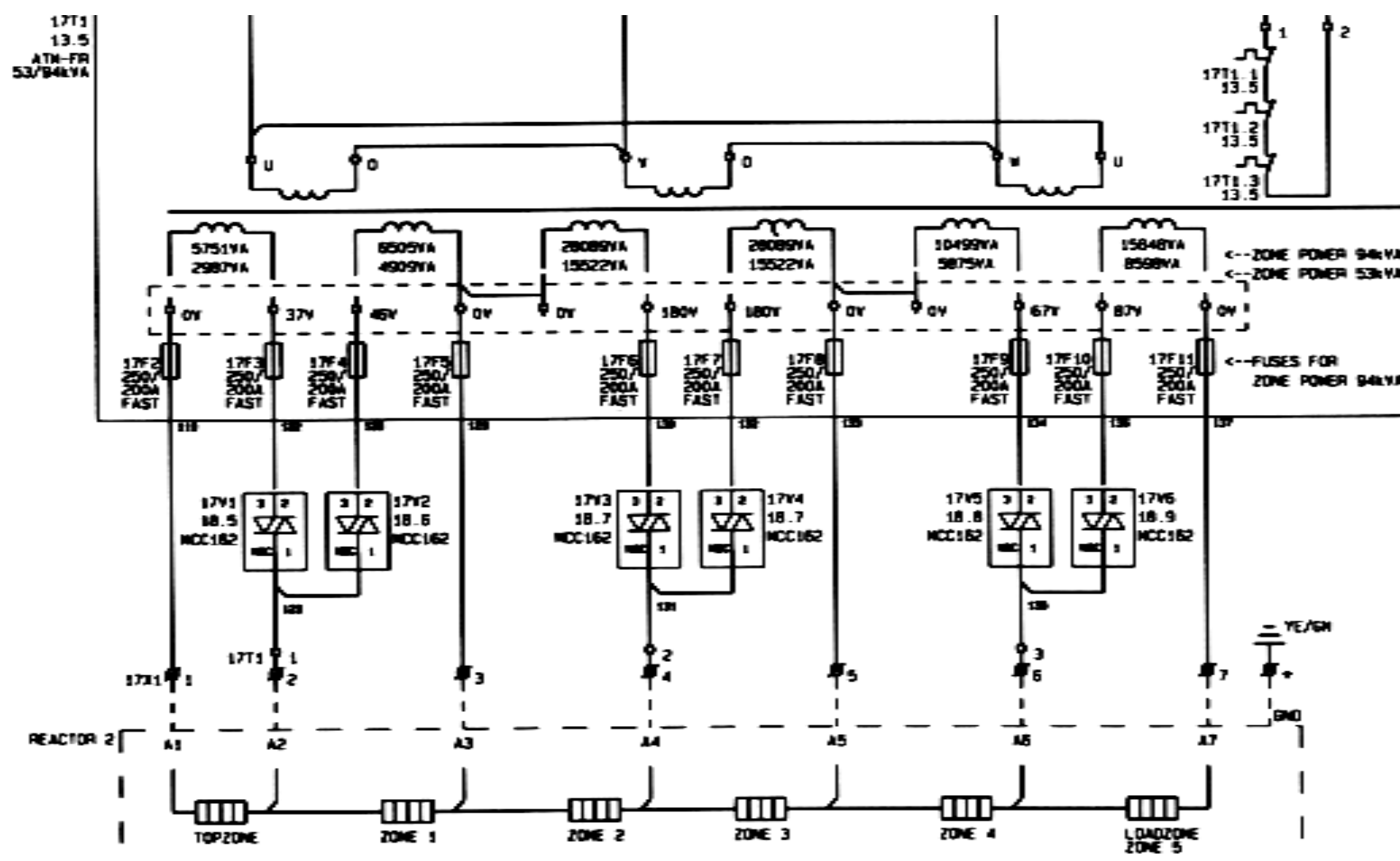

Figure 7 temperature control circuit of 12 "experimental testfurnace 


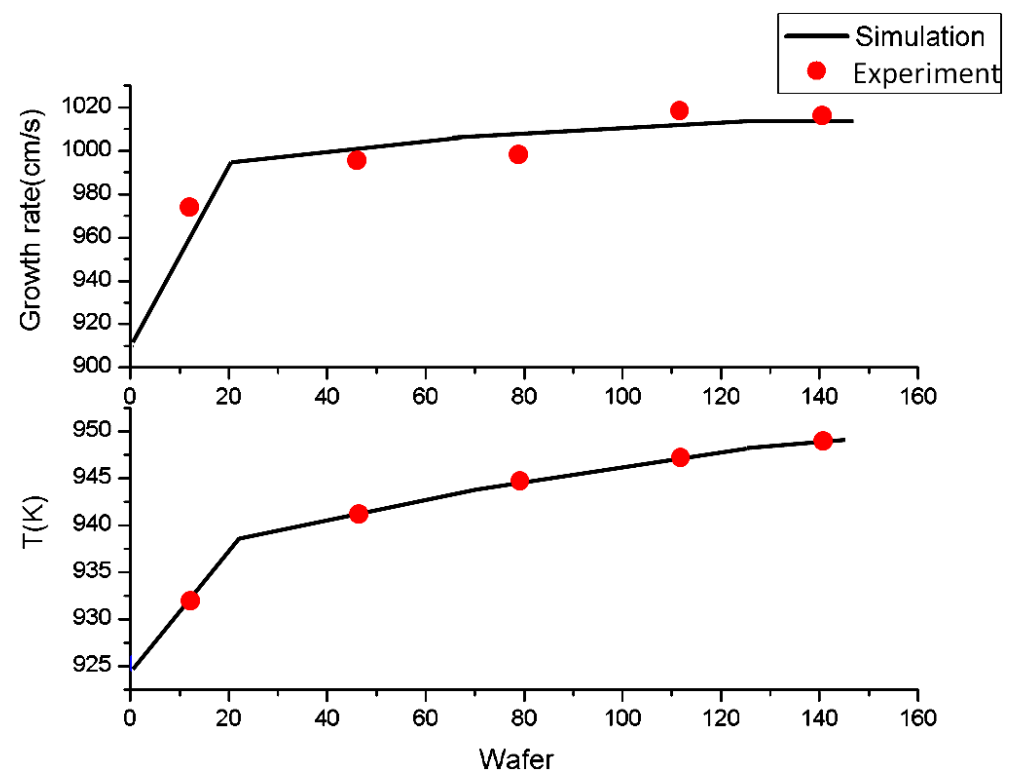

Figure 8 simulationand experiment resultsof non-process wafers

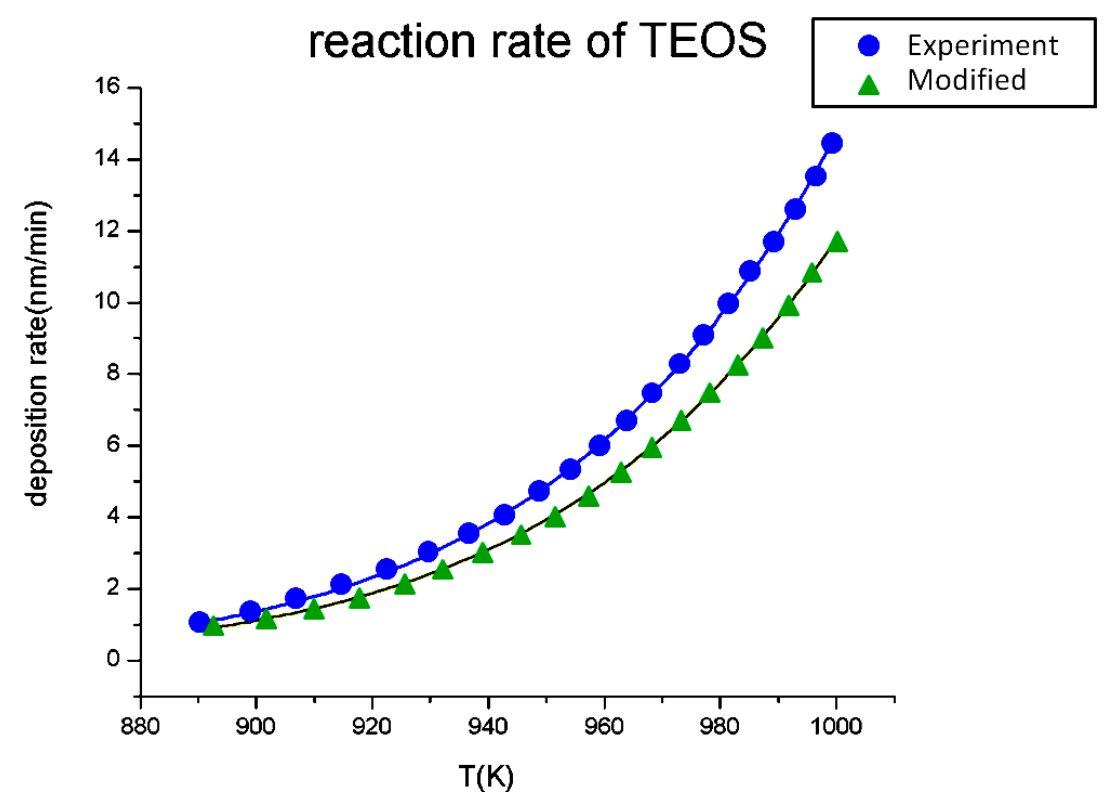

Figure 9 relations of reactionrate andtemperatureof TEOS 


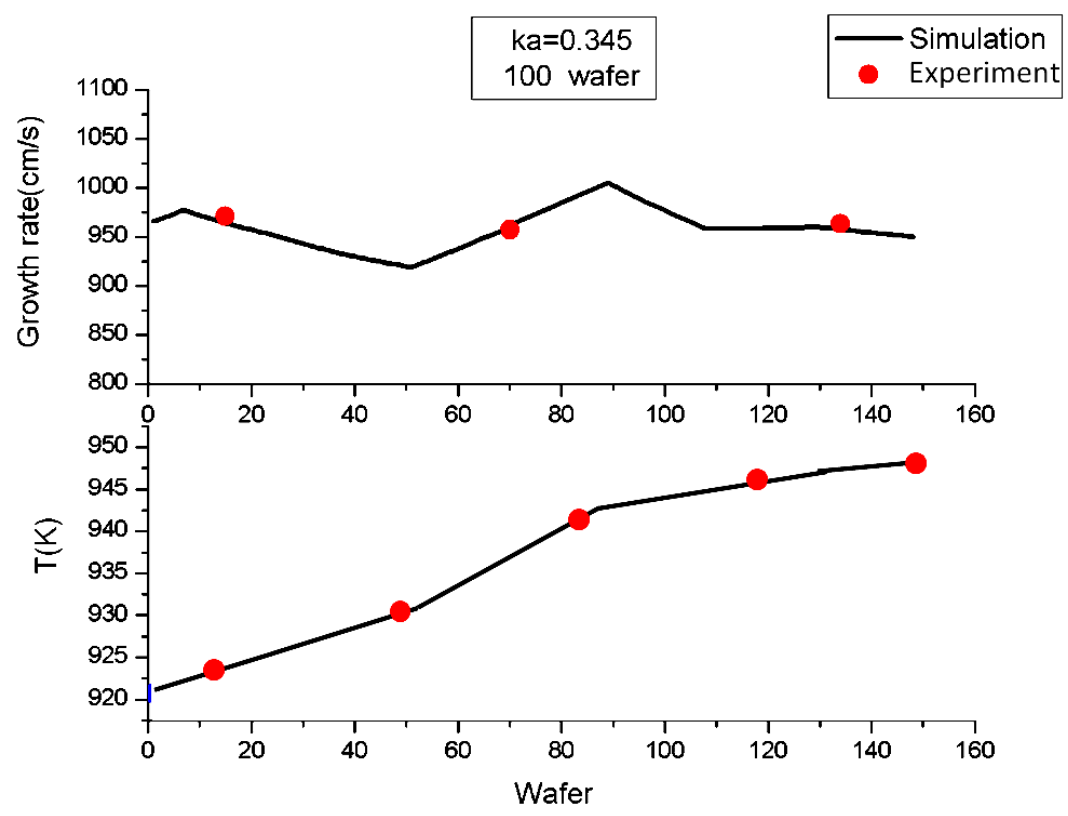

Figure 10 simulationand experimental results of first lot

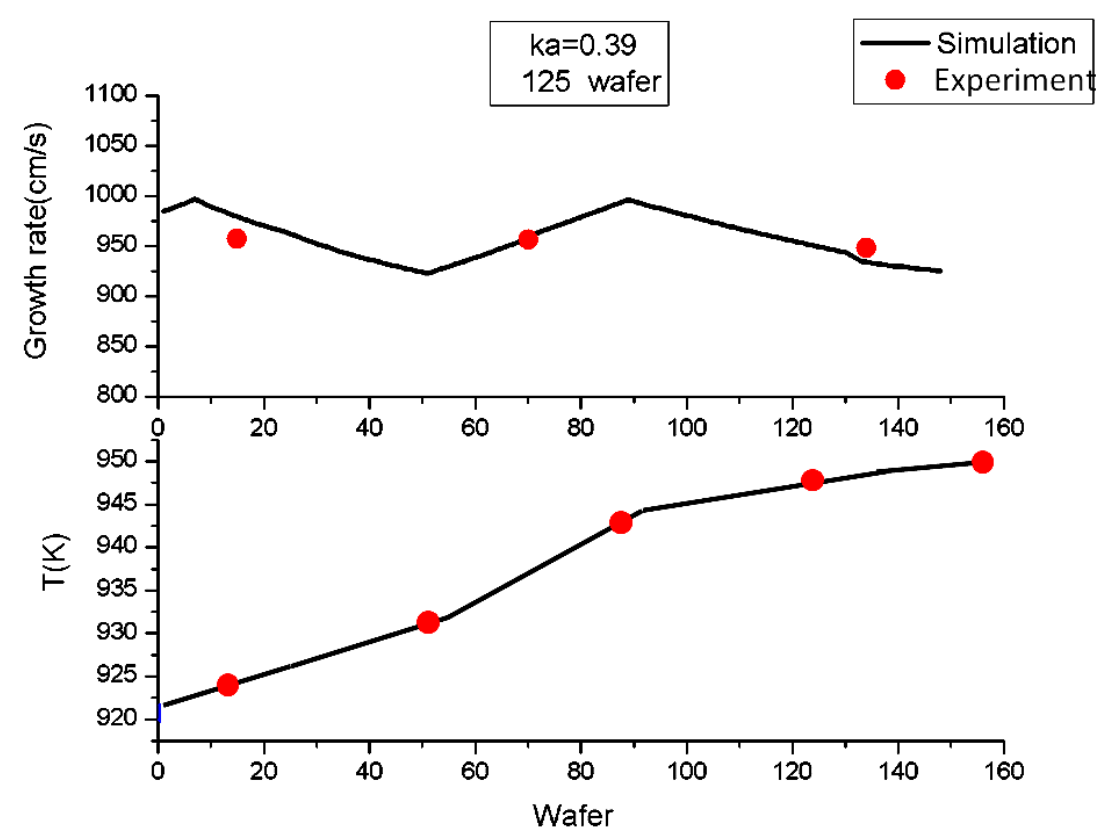

Figure 11 simulationand experimental results of second lot 


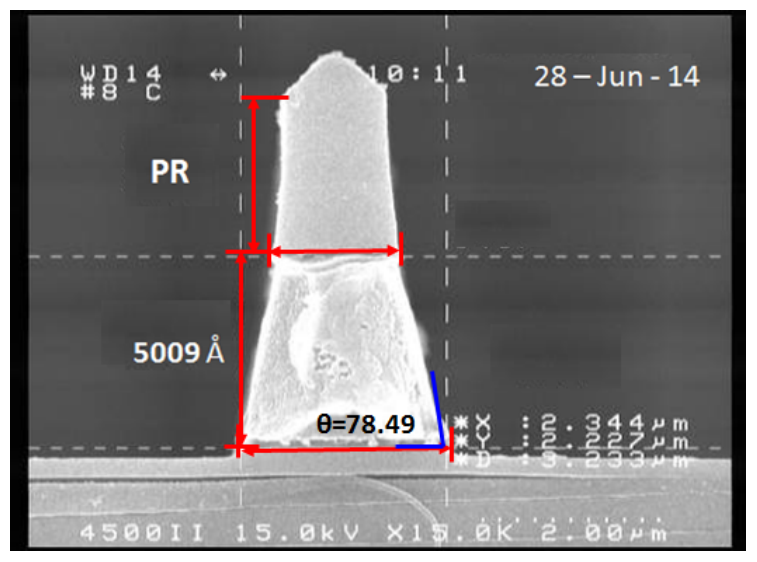

Figure 12 the SEM thin film checking after process about $5009 \AA$

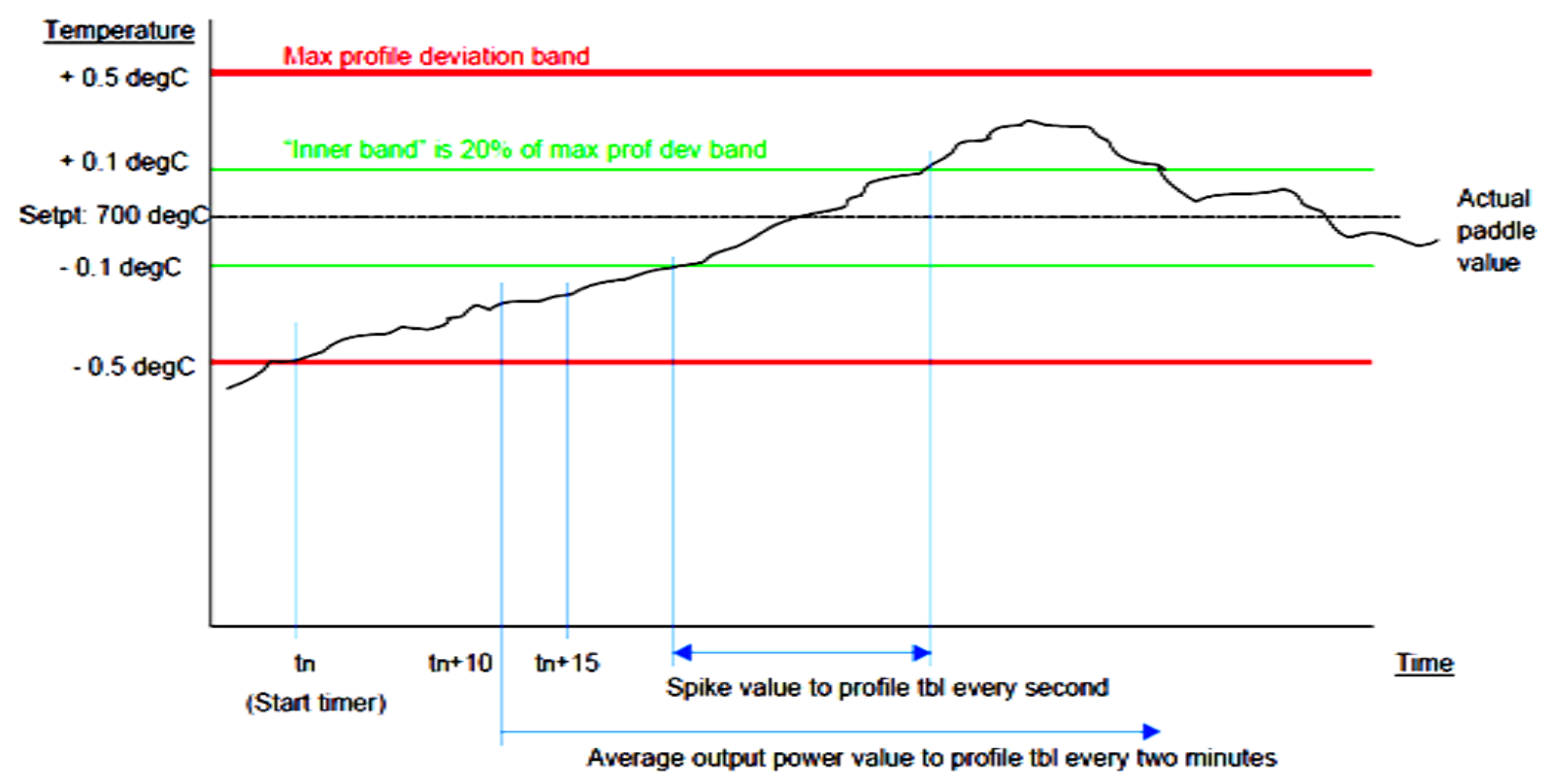

Figure 13Detailedcontrol profile ofone heating zonetemperature 


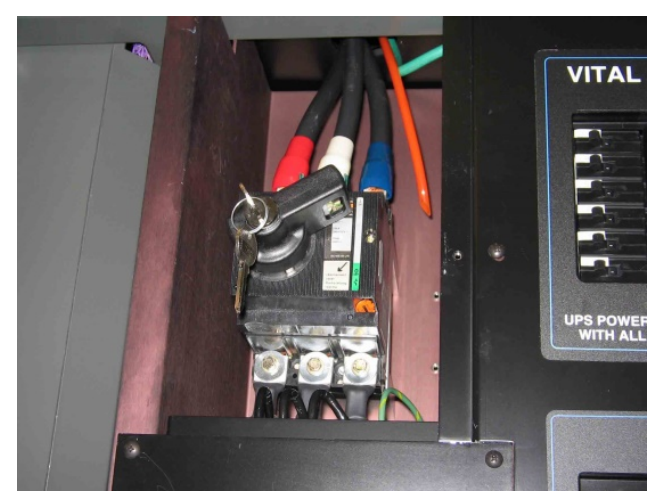

(a) Normal situation

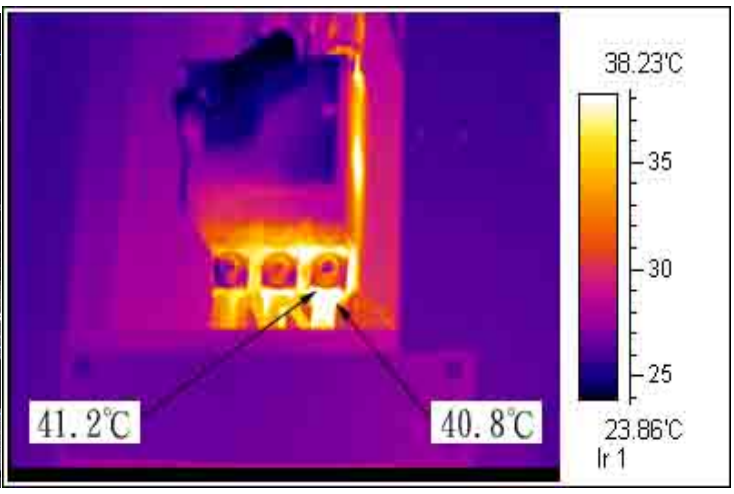

(b) Infrared detecting image

Figure 14 Infrared detecting for 12” furnace

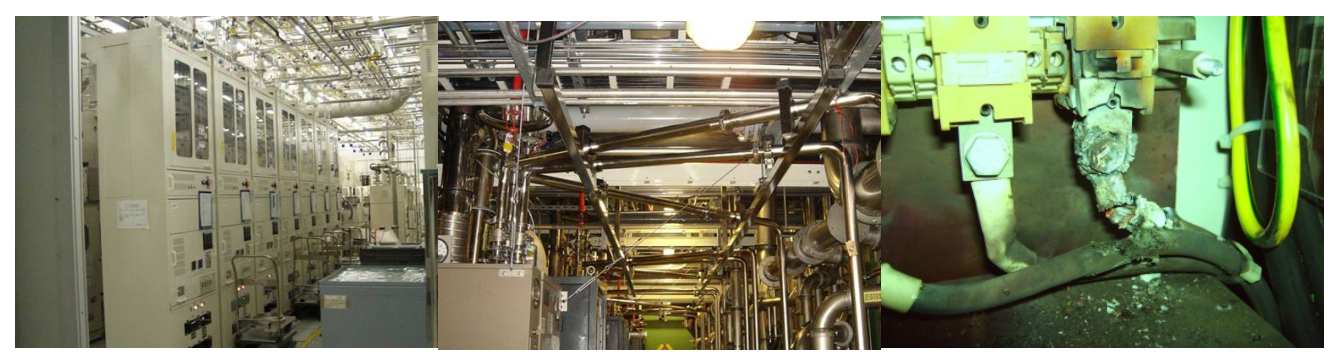

(a)thermal process area in clean room(b)tool piping in sub-fab

(c)terminals burning of heating zone

Figure 15Commercialmanufacturingplantenvironment andenergyhazards 


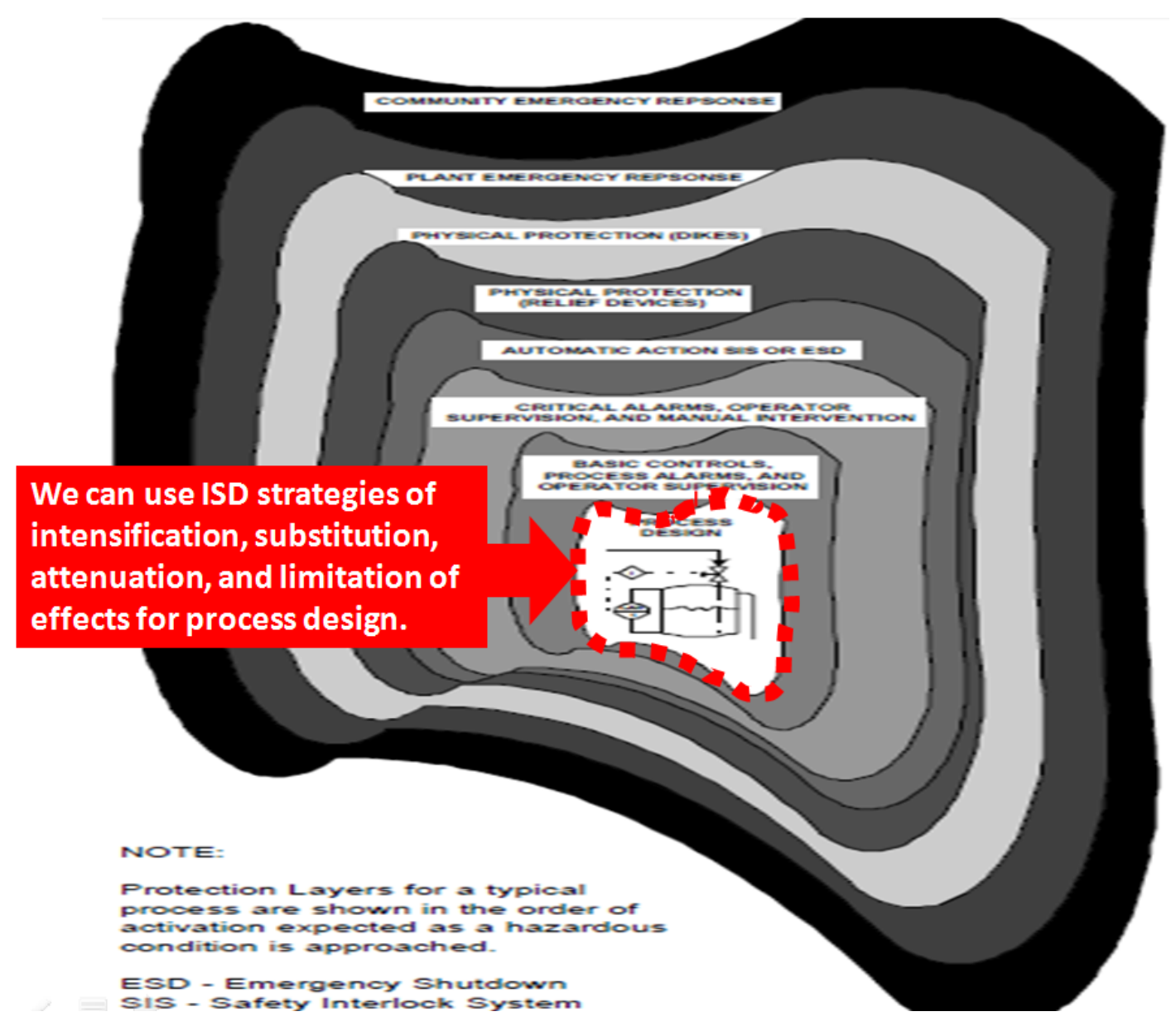

Figure 16Inherently saferdesignapplication strategy in chemical process and plant 
Table 1 Summary of the importance changes in advanced 22nm IC processes

\begin{tabular}{|c|c|c|c|c|}
\hline $\begin{array}{c}\text { Devicestructur } \\
\text { e }\end{array}$ & Position of importance changes & $\begin{array}{c}\text { Propertychange } \\
\text { of Materials }\end{array}$ & $\begin{array}{c}\text { Safety refocused } \\
\text { of process } \\
\text { change }\end{array}$ & $\begin{array}{l}\text { Analysis of } \\
\text { Safety and health } \\
\text { management } \\
\text { issues }\end{array}$ \\
\hline Metal Gate & 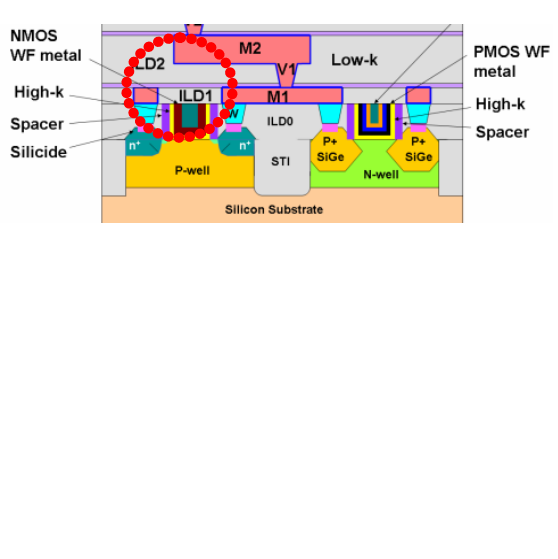 & $\begin{array}{l}\text { Replacepolysilic } \\
\text { ongateadoptedto } \\
\text { reducegateresista } \\
\text { nce. }\end{array}$ & $\begin{array}{l}\text { Raw material } \\
\text { changedfrom } \\
\text { explosions(Silan } \\
\text { e) to metalvapor. }\end{array}$ & $\begin{array}{l}\text { Thischangeis } \\
\text { moresafety then } \\
\text { before process } \\
\text { condition, butthe } \\
\text { new processwill } \\
\text { be increases } \\
\text { themetalexhaustp } \\
\text { articulatesharmfu } \\
\text { l. }\end{array}$ \\
\hline $\begin{array}{c}\text { Channels of } \\
\text { Sourceand } \\
\text { Drain }\end{array}$ & 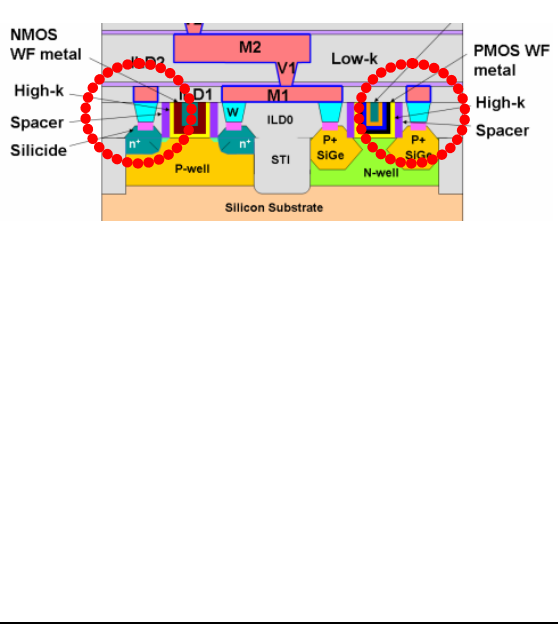 & $\begin{array}{l}\text { Enhancedthe } \\
\text { mobilityof } \\
\text { electrons } \\
\text { andholes, and } \\
\text { then } \\
\text { improvedthe } \\
\text { speed ofthe } \\
\text { device. }\end{array}$ & $\begin{array}{l}\text { Using epitaxial } \\
\text { growthtoproduce } \\
\text { asilicidegermani } \\
\text { um } \\
\text { (SiGe)andsilicon } \\
\text { carbide(SiC). }\end{array}$ & $\begin{array}{l}\text { Increasedthe } \\
\text { process safety } \\
\text { managementcom } \\
\text { plexity cause by } \\
\text { in addition tothe } \\
\text { originalionimpla } \\
\text { ntation process, } \\
\text { but } \\
\text { alsoaddingepitax } \\
\text { yprocess,. }\end{array}$ \\
\hline $\begin{array}{l}\text { Technology of } \\
\text { self-alignedCo } \\
\text { WP } \\
\text { non-electroplat } \\
\text { ing }\end{array}$ & $\begin{array}{l}\text { NMOS } \\
\text { WF metal } \\
\text { High-k } \\
\text { Spacer } \\
\text { silicide }\end{array}$ & $\begin{array}{l}\text { The } \\
\text { coveringcoppers } \\
\text { urface } \\
\text { technologyforusi } \\
\text { ng in after } \\
\text { CMP(Chemical } \\
\text { MechanicalPolis } \\
\text { hing, CMP) } \\
\text { process. }\end{array}$ & $\begin{array}{l}\text { Prevented } \\
\text { thediffusion of } \\
\text { copperthen } \\
\text { reducedelectro } \\
\text { migration,and } \\
\text { then improved } \\
\text { the reliability } \\
\text { ofthe } \\
\text { copperwireconne } \\
\text { ction. }\end{array}$ & $\begin{array}{l}\text { Increased } \\
\text { processsteps, } \\
\text { andchemicals } \\
\text { usage, then } \\
\text { hazardous will } \\
\text { be raised. }\end{array}$ \\
\hline
\end{tabular}




\begin{tabular}{|c|c|c|c|c|}
\hline $\begin{array}{l}\text { Hardmasklayer } \\
\text { of Metal(TiN) }\end{array}$ & 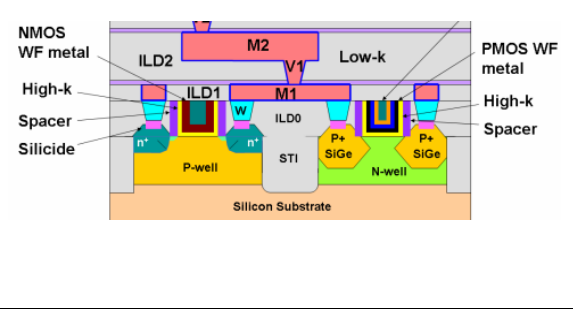 & $\begin{array}{l}\text { For used in the } \\
\text { low-k dielectric } \\
\text { etch Mask layer. }\end{array}$ & $\begin{array}{l}\text { ImprovedMask } \\
\text { layerhardnesstoe } \\
\text { nsure a } \\
\text { low-kdielectric } \\
\text { etchesquality. }\end{array}$ & $\begin{array}{l}\text { The hazardous } \\
\text { no difference } \\
\text { after process } \\
\text { reactivematerials } \\
\text { change. }\end{array}$ \\
\hline $\begin{array}{l}\text { Immersion } \\
\text { lithographytec } \\
\text { hnology of } \\
\text { 193nm }\end{array}$ & $\begin{array}{l}\text { Projection lens } \\
\text { Scanning motion }\end{array}$ & $\begin{array}{l}\text { Increased to use } \\
\text { ofDI waterin } \\
\text { photolithography } \\
\text { process then } \\
\text { reached effect of } \\
\text { immersion. }\end{array}$ & $\begin{array}{l}\text { Immersion } \\
\text { effectivelymakes } \\
\text { lithographyresol } \\
\text { utionto continue } \\
\text { andremain } \\
\text { at22nm. }\end{array}$ & $\begin{array}{l}\text { Process } \\
\text { machinebecomes } \\
\text { more } \\
\text { complex,mainten } \\
\text { ance } \\
\text { personnelwill be } \\
\text { increaseoperatin } \\
\text { g time, and then } \\
\text { increased the } \\
\text { chance ofcontact } \\
\text { withhazardousm } \\
\text { aterial. }\end{array}$ \\
\hline $\begin{array}{l}\text { Lead-free } \\
\text { solder }\end{array}$ & мэ & $\begin{array}{l}\text { Reducedto use } \\
\text { the lead solder. }\end{array}$ & $\begin{array}{l}\text { Due to } \\
\text { technicalupgradi } \\
\text { ng, usingthe } \\
\text { lead-freesolderca } \\
\text { n continue } \\
\text { toreachthe } \\
\text { weldingpurposes } \\
\text {. }\end{array}$ & $\begin{array}{l}\text { Reducingleadfu } \\
\text { megeneratedopp } \\
\text { ortunities, and } \\
\text { thenreduced } \\
\text { hazard level } \\
\text { andsafety } \\
\text { upgrade. }\end{array}$ \\
\hline
\end{tabular}


Table 2 Analysis hazardsin advanced22nmIC process, equipment, and facility system

\begin{tabular}{|c|c|c|}
\hline process steps & Function and composition ofprocess machines & Analysisof Potential hazards \\
\hline Block Growth & $\begin{array}{l}\text { Agencies,cooling system, pressure gauges, } \\
\text { control valves, motors, piping, wiring, } \\
\text { monitoring system. }\end{array}$ & $\begin{array}{l}\text { High-Temperature, Gas Leak, Fire, } \\
\text { Explosion, Shock, Rolling } \\
\text { andCrimping }\end{array}$ \\
\hline $\begin{array}{l}\text { Wafer Cutting and } \\
\text { Polishing }\end{array}$ & $\begin{array}{l}\text { Reactor, display screen, control panel, driving } \\
\text { elements, agencies, grinding } \\
\text { wheels, wirecutting body, piping, wiring, } \\
\text { monitoring system. }\end{array}$ & $\begin{array}{l}\text { OrganicSolventPoisoning, Acid } \\
\text { and Alkali corrosion, Shock, } \\
\text { Rolling andCrimping, Hitting, } \\
\text { Cutting. }\end{array}$ \\
\hline $\begin{array}{l}\text { Oxidation and } \\
\text { Thermal Processing }\end{array}$ & $\begin{array}{l}\text { Wafertransfer system, agencies, } \\
\text { Heatdissipation, air filtration, heaters, power } \\
\text { supply system, piping, wiring, monitoring } \\
\text { system. }\end{array}$ & $\begin{array}{l}\text { High-Temperature, Fire,Explosion, } \\
\text { Shock, Rolling andCrimping. }\end{array}$ \\
\hline Diffusion & $\begin{array}{l}\text { Wafertransfer system, agencies,cooling } \\
\text { system,air filtration,heaters, power supply } \\
\text { system, piping, wiring, monitoring system. }\end{array}$ & $\begin{array}{l}\text { High-Temperature,Gas } \\
\text { Leak,Fire,Explosion,Shock, } \\
\text { Rolling andCrimping. }\end{array}$ \\
\hline $\begin{array}{l}\text { Physical Vapor } \\
\text { Deposition, PVD }\end{array}$ & $\begin{array}{l}\text { Wafertransfer system, Reactor, power supply } \\
\text { system,Isolation valves, refrigeration } \\
\text { valves,mechanical pump, piping, wiring, } \\
\text { monitoring system. }\end{array}$ & $\begin{array}{l}\text { High-Temperature,Gas } \\
\text { Leak,Fire,Explosion,Shock, } \\
\text { Rolling andCrimping. }\end{array}$ \\
\hline $\begin{array}{l}\text { ChemicalVapor } \\
\text { Deposition, CVD }\end{array}$ & $\begin{array}{l}\text { Wafertransfer system, Reactor, controller, gas } \\
\text { supply system, vacuum system, grounding, } \\
\text { piping, wiring, monitoring system. }\end{array}$ & $\begin{array}{l}\text { High-Temperature,Gas Leak,Acid } \\
\text { and Alkali } \\
\text { corrosion,Fire,Explosion,Shock, } \\
\text { Rolling andCrimping. }\end{array}$ \\
\hline Photo Lithography & $\begin{array}{l}\text { Wafertransfer system,spin chamber, photoresist } \\
\text { (PR)coating,Robot arm,vacuum system, } \\
\text { agencies, grounding, rotator, soft baking } \\
\text { element, piping, wiring, monitoring system. }\end{array}$ & $\begin{array}{l}\text { High-Temperature,Gas Leak, Acid } \\
\text { and Alkali } \\
\text { corrosion,Fire,Explosion,Shock, } \\
\text { Rolling andCrimping. }\end{array}$ \\
\hline Etching & $\begin{array}{l}\text { Wafertransfer system, Reactor,Electrode plate, } \\
\text { wafer boat,magnet coil, vacuum system, RF } \\
\text { generator, gassupplyand control system, } \\
\text { grounding, cooling water systems,piping, } \\
\text { wiring, monitoring system. }\end{array}$ & $\begin{array}{l}\text { High-Temperature,Gas Leak, Acid } \\
\text { and Alkali } \\
\text { corrosion,Fire,Explosion,Shock, } \\
\text { Rolling andCrimping, Radiation. }\end{array}$ \\
\hline
\end{tabular}




\begin{tabular}{|c|c|c|}
\hline Ion Implantation & $\begin{array}{l}\text { Wafertransfersystem, agencies,ionsource } \\
\text { supply system, filter, ion analysis device, } 4 \\
\text { pole focusing, electrostatic deflector, scanner, } \\
\text { magnetic lens, accelerator, } \\
\text { crystalholder,Faraday cup, cryogenic pumps, } \\
\text { grounding, cooling water systems,piping, } \\
\text { wiring, monitoring system. }\end{array}$ & $\begin{array}{l}\text { High-Temperature,Gas Leak, Acid } \\
\text { and Alkali } \\
\text { corrosion,Fire,Explosion,Shock, } \\
\text { Rolling andCrimping, Radiation. }\end{array}$ \\
\hline $\begin{array}{l}\text { Chemical } \\
\text { MechanicalPolishing, } \\
\text { CMP }\end{array}$ & $\begin{array}{l}\text { Wafertransfersystem, polishing apparatus, } \\
\text { agencies, polishingchamber, brushing device, } \\
\text { piping, wiring,monitoring system. }\end{array}$ & $\begin{array}{l}\text { Gas Leak, Acid and Alkali } \\
\text { corrosion,Fire,Explosion,Shock, } \\
\text { Rolling andCrimping. }\end{array}$ \\
\hline $\begin{array}{l}\text { Clean } \\
\text { process(Wet } \\
\text { Bench) }\end{array}$ & $\begin{array}{l}\text { Wafertransfersystem, cleanchamber,wafer } \\
\text { carrier, steam drying system, robot arm, } \\
\text { agencies,piping, wiring, monitoring system. }\end{array}$ & $\begin{array}{l}\text { Gas Leak, Acid and Alkali } \\
\text { corrosion,Fire,Explosion,Shock, } \\
\text { Rolling andCrimping. }\end{array}$ \\
\hline Packing process & $\begin{array}{l}\text { Waferassembly platform, wafer transfer } \\
\text { system, visuallylens group, ejection } \\
\text { mechanism, lead frame, lead frametransfer } \\
\text { mechanism, gluingmechanism, pick and place } \\
\text { mechanism, agencies,piping, wiring, } \\
\text { monitoring system. }\end{array}$ & $\begin{array}{l}\text { Gas Leak,High-Temperature, Acid } \\
\text { and Alkali corrosion, Fire, } \\
\text { Explosion,Shock, Rolling } \\
\text { andCrimping, Hitting, Collapsing. }\end{array}$ \\
\hline Facility system & $\begin{array}{l}\text { Clean rooms, offices, rawmaterial } \\
\text { storageroom,channel, chemicals } \\
\text { rooms,electricalrooms,ventilation system, } \\
\text { piping andracks,outdoorstorage tanks, } \\
\text { wastewater treatment facilities. }\end{array}$ & $\begin{array}{l}\text { Gas Leak,High-Temperature, Acid } \\
\text { and Alkali corrosion, Fire, } \\
\text { Explosion,Shock, Rolling } \\
\text { andCrimping, Hitting, Collapsing, } \\
\text { Drowning,hypoxia. }\end{array}$ \\
\hline
\end{tabular}


Table 3 thethin film materials of CVD process used

\begin{tabular}{|c|c|c|}
\hline $\begin{array}{l}\text { Application on } \\
\text { IC(Integrated Circuit) }\end{array}$ & $\begin{array}{l}\text { types of Thin } \\
\text { Film }\end{array}$ & Raw Materials \\
\hline & Si(poly) & SiH4(silane) \\
\hline Semiconductor & Si(epi) & $\begin{array}{l}\text { SiCl2H2(DCS) } \\
\text { SiCl3H(TCS) } \\
\text { SiCl4(Siltet) }\end{array}$ \\
\hline \multirow[t]{3}{*}{ Dielectrics } & Silicon oxide & $\begin{array}{c}\text { SiH4, O2 } \\
\text { SiH4, N2O } \\
\text { Si(OC } 2 \text { H5) } 4 \text { (TEOS), O } 2 \\
\text { TEOS } \\
\text { TEOS, O3(ozone) }\end{array}$ \\
\hline & Oxynitride & $\begin{array}{c}\mathrm{SiH} 4, \mathrm{~N} 2 \mathrm{O}, \mathrm{N} 2, \mathrm{NH} 3 \\
\mathrm{SiH} 4, \mathrm{~N} 2, \mathrm{NH} 3 \\
\mathrm{SiH} 4, \mathrm{~N} 2, \mathrm{NH} 3\end{array}$ \\
\hline & $\mathrm{Si} 3 \mathrm{H} 4$ & C8H22N2Si(BTBAS) \\
\hline \multirow{3}{*}{ Conductors } & W(tungsten) & $\begin{array}{c}\text { WF6(tungsten } \\
\text { hexafluoride), SiH4, H2 }\end{array}$ \\
\hline & WSi2 & $\begin{array}{c}\text { WF6(tungsten } \\
\text { hexafluoride), SiH4, H2 }\end{array}$ \\
\hline & TiN & Ti[N(CH3)2]4(TDMAT) \\
\hline
\end{tabular}




\begin{tabular}{|c|c|c|}
\hline \multirow{2}{*}{$\mathrm{Ti}$} & $\mathrm{TiCl}$ \\
\cline { 2 - 3 } & $\mathrm{Cu}$ & (hfac)Cu(tmvs) \\
\hline
\end{tabular}

Table 4 related materials andreactor types of CVD

\begin{tabular}{|c|c|c|}
\hline Types of thin film & materials & reactor types of CVD \\
\hline \multirow{7}{*}{$\begin{array}{l}\text { Thin film of } \\
\text { Dielectric Materials }\end{array}$} & $\mathrm{SiO}_{2}$ & AP,LP,PE,HDP \\
\hline & PSG & AP,PE \\
\hline & BSG & $\mathrm{AP}, \mathrm{PE}$ \\
\hline & BPSG & AP,LP,PE \\
\hline & $\mathrm{Si}_{3} \mathrm{~N}_{4}$ & LP,PE \\
\hline & $\mathrm{SiO}_{\mathrm{x}} \mathrm{N}_{\mathrm{y}}$ & $\mathrm{PE}$ \\
\hline & Polysilicon & LP \\
\hline \multirow{4}{*}{$\begin{array}{l}\text { Thin film of } \\
\text { Conductive material }\end{array}$} & WSix & LP \\
\hline & W & LP \\
\hline & $\mathrm{TiN} / \mathrm{Ti}$ & LP,PE(MO) \\
\hline & $\mathrm{Cu}$ & LP,PE(MO) \\
\hline \multirow{2}{*}{$\begin{array}{c}\text { Thin film of low-k } \\
\text { materials }\end{array}$} & Carbon-dopedSiO2 & $\mathrm{PE}$ \\
\hline & $\begin{array}{c}\text { Carbon-dopedamorphous } \\
\text { silicon }\end{array}$ & $\mathrm{PE}$ \\
\hline \multirow{2}{*}{$\begin{array}{c}\text { Thin film of high-k } \\
\text { materials }\end{array}$} & $\mathrm{Ta}_{2} \mathrm{O}_{5}$ & $\mathrm{LP}(\mathrm{MO})$ \\
\hline & BST & $\mathrm{LP}(\mathrm{MO})$ \\
\hline \multicolumn{3}{|c|}{ PSG: Phosphor Silicate glass } \\
\hline \multicolumn{3}{|c|}{ BSG: Boron-Silicateglass } \\
\hline \multicolumn{3}{|c|}{ BPSG: Boron and Phosphor Silicate glass } \\
\hline \multicolumn{3}{|c|}{ BST: Ba0.5Sr0.5TiO3 } \\
\hline \multicolumn{3}{|l|}{ AP: Atmospheric CVD } \\
\hline \multicolumn{3}{|l|}{ LP: Lowpressure CVD } \\
\hline \multicolumn{3}{|c|}{ PE: Plasma enhanced CVD } \\
\hline \multicolumn{3}{|c|}{ HDP: High-density plasma CVD } \\
\hline \multicolumn{3}{|c|}{ MO: Metal-Organic CVD } \\
\hline
\end{tabular}


Table 5 conditions of LPCVD reactor in this study

\begin{tabular}{|c|c|}
\hline Condition & Unit \\
\hline Inlet gas flow rate : TEOS & $380 \mathrm{sccm}$ \\
\hline Pressure & 0.6 Torr \\
\hline Tube diameter & $435 \mathrm{~mm}$ \\
\hline Wafer diameter & $300 \mathrm{~mm}$ \\
\hline Tube length & $1215 \mathrm{~mm}$ \\
\hline Rotation rate & $2 \mathrm{rpm}$ \\
\hline Deposition time & $24.2 \mathrm{~min}$ \\
\hline Wafer & $125 \mathrm{wafers}$ \\
\hline Side Dummy : Top & $14^{\text {th }}$ \\
\hline Side Dummy : Bottom & $6^{\text {th }}$ \\
\hline Monitor & 3 wafers \\
\hline Capacity & $148 \mathrm{wafers}$ \\
\hline
\end{tabular}

Table 6 each heating zone running current of 100 wafers

\begin{tabular}{|c|c|c|c|c|c|}
\cline { 2 - 6 } \multicolumn{1}{c|}{} & \multicolumn{5}{c|}{ Current Value (A) } \\
\hline Process time & Zone1 & Zone2 & Zone3 & Zone4 & Zone5 \\
\hline $10 \mathrm{~min}$ & 15.89 & 16.63 & 17.71 & 17.78 & 0 \\
\hline $20 \mathrm{~min}$ & 15.99 & 17.67 & 17.79 & 17.84 & 0 \\
\hline $30 \mathrm{~min}$ & 16.16 & 17.70 & 17.80 & 17.87 & 0 \\
\hline 40min & 16.38 & 17.74 & 17.81 & 17.90 & 0 \\
\hline 50min & 16.75 & 17.78 & 17.84 & 17.92 & 0 \\
\hline Average & 16.23 & 17.50 & 17.79 & 17.86 & 0 \\
\hline
\end{tabular}


Table 7 each heating zone running current of 125 wafers

\begin{tabular}{|c|c|c|c|c|c|}
\hline & \multicolumn{5}{|c|}{ Current Value (A) } \\
\hline Process time & Zone1 & Zone2 & Zone3 & Zone4 & Zone5 \\
\hline $10 \mathrm{~min}$ & 15.87 & 16.65 & 17.7 & 17.77 & 17.86 \\
\hline $20 \mathrm{~min}$ & 15.97 & 17.67 & 17.81 & 17.85 & 17.99 \\
\hline $30 \mathrm{~min}$ & 16.18 & 17.73 & 17.83 & 17.89 & 18.07 \\
\hline $40 \mathrm{~min}$ & 16.35 & 17.77 & 17.89 & 17.92 & 18.15 \\
\hline $50 \mathrm{~min}$ & 16.78 & 17.8 & 17.95 & 17.95 & 18.21 \\
\hline Average & 16.23 & 17.52 & 17.83 & 17.87 & 18.05 \\
\hline
\end{tabular}


Table 8FMEAanalysis results of temperature control system for12” furnace tools

\begin{tabular}{|c|c|c|c|c|c|c|c|c|}
\hline $\begin{array}{c}\text { Name of } \\
\text { parts } \\
\text { (Part No.) }\end{array}$ & $\begin{array}{l}\text { Failure } \\
\text { mode }\end{array}$ & Cause of failure & $\begin{array}{l}\text { Method of cognitive } \\
\text { failure }\end{array}$ & Effect & $\begin{array}{l}\text { Seve- } \\
\text { rity }\end{array}$ & $\begin{array}{l}\text { Like- } \\
\text { lihood }\end{array}$ & $\begin{array}{l}\text { Protective } \\
\text { equipment }\end{array}$ & $\begin{array}{l}\text { Remarks or } \\
\text { description }\end{array}$ \\
\hline $\begin{array}{l}\text { Element } \\
\text { control } \\
\text { panel } \\
\text { (HZ-001) }\end{array}$ & $\begin{array}{l}\text { The control } \\
\text { circuit } \\
\text { board } \\
\text { failure }\end{array}$ & $\begin{array}{l}\text { 1.Electronic } \\
\text { Components } \\
\text { burned } \\
\text { 2.Open or short } \\
\text { circuit } \\
\text { 3.Control operation } \\
\text { interface failure }\end{array}$ & $\begin{array}{l}\text { 1.Inoperable and } \\
\text { uncontrolled temperature } \\
\text { 2.Scorch smell }\end{array}$ & $\begin{array}{l}\text { 1. Overheat and catch fire } \\
\text { 2.Defective products } \\
\text { 3.Process no action } \\
\text { 4.Unable to control process tool } \\
\text { power consumption }\end{array}$ & 3 & 0.0002 & Yes & $\begin{array}{l}\text { System circuit } \\
\text { breaker protection } \\
\text { and warning light }\end{array}$ \\
\hline $\begin{array}{l}\text { Temperatur } \\
\text { e display } \\
\text { (HZ-002) }\end{array}$ & $\begin{array}{l}\text { Display and } \\
\text { circuit failure }\end{array}$ & $\begin{array}{l}\text { 1. Display board } \\
\text { failure } \\
\text { 2. Open or short } \\
\text { circuit }\end{array}$ & $\begin{array}{l}\text { 1. Operating temperature } \\
\text { cannot be displayed or } \\
\text { display is unstable } \\
\text { 2.Scorch smell }\end{array}$ & $\begin{array}{l}\text { 1. The actual temperature value is } \\
\text { unknown } \\
\text { 2. Defective products }\end{array}$ & 2 & 0.001 & No & $\begin{array}{l}\text { Available to use } \\
\text { infrared } \\
\text { temperature } \\
\text { equipment to get } \\
\text { the actual } \\
\text { temperature }\end{array}$ \\
\hline $\begin{array}{l}\text { Digital } \\
\text { process } \\
\text { controller } \\
\text { (HZ-003) }\end{array}$ & $\begin{array}{l}\text { The control } \\
\text { circuit } \\
\text { board } \\
\text { failure }\end{array}$ & $\begin{array}{l}\text { 1.Electronic } \\
\text { Components } \\
\text { burned } \\
\text { 2.Open or short } \\
\text { circuit } \\
\text { 3.Digital } \\
\text { computing } \\
\text { interference }\end{array}$ & $\begin{array}{l}\text { 1.Process stops } \\
\text { functioning andwarning } \\
\text { lighting } \\
\text { 2.Scorch smell }\end{array}$ & Process stops functioning & 1 & 0.001 & Yes & $\begin{array}{l}\text { The reaction gases } \\
\text { linked and stopped } \\
\text { supply and process } \\
\text { automatically }\end{array}$ \\
\hline $\begin{array}{l}\text { Power } \\
\text { supply unit } \\
\text { (HZ-004) }\end{array}$ & $\begin{array}{l}\text { The control } \\
\text { circuit } \\
\text { board } \\
\text { failure }\end{array}$ & $\begin{array}{l}\text { 1.Electronic } \\
\text { Components } \\
\text { burned } \\
\text { 2.Open or short } \\
\text { circuit } \\
\end{array}$ & $\begin{array}{l}\text { 1.Unable to control } \\
\text { fiveheating zone } \\
\text { 2. Scorch smell }\end{array}$ & $\begin{array}{l}\text { 1. Overheat and catch fire } \\
\text { 2.Defective products }\end{array}$ & 3 & 0.003 & Yes & $\begin{array}{l}\text { Systemcircuit } \\
\text { breaker } \\
\text { protectionand } \\
\text { warning light }\end{array}$ \\
\hline $\begin{array}{l}\text { Digital } \\
\text { temperature } \\
\text { controller }\end{array}$ & $\begin{array}{l}\text { The control } \\
\text { circuit } \\
\text { board }\end{array}$ & $\begin{array}{l}\text { 1.Electronic } \\
\text { Components } \\
\text { burned }\end{array}$ & $\begin{array}{l}\text { 1.Process stops } \\
\text { functioning andwarning } \\
\text { lighting }\end{array}$ & $\begin{array}{l}\text { 1. Overheat and catch fire } \\
\text { 2.Defective products }\end{array}$ & 3 & 0.001 & Yes & $\begin{array}{l}\text { System circuit } \\
\text { breaker } \\
\text { protectionand }\end{array}$ \\
\hline
\end{tabular}




\begin{tabular}{|c|c|c|c|c|c|c|c|c|}
\hline (HZ-005) & failure & $\begin{array}{l}\text { 2.Open or short } \\
\text { circuit } \\
\text { 3.Digital } \\
\text { computing } \\
\text { interference } \\
\end{array}$ & 2.Scorch smell & & & & & warning light \\
\hline $\begin{array}{l}\text { Heating } \\
\text { element } \\
1 \sim 5 \\
(\text { HZ-006) }\end{array}$ & $\begin{array}{l}\text { Heating } \\
\text { element } \\
\text { failure }\end{array}$ & $\begin{array}{l}\text { 1. Heating } \\
\text { elements burned } \\
\text { 2. Open or short } \\
\text { circuit } \\
\text { 3. Ohmic contact is } \\
\text { too large }\end{array}$ & $\begin{array}{l}\text { 1.Process stops } \\
\text { functioning andwarning } \\
\text { lighting } \\
\text { 2. Scorch smell }\end{array}$ & $\begin{array}{l}\text { 1. Overheat and catch fire } \\
\text { 3.VESDA system action }\end{array}$ & 4 & 0.07 & Yes & $\begin{array}{l}\text { 1.System circuit } \\
\text { breaker protection } \\
\text { and warning light } \\
\text { 2. VESDA system } \\
\text { established }\end{array}$ \\
\hline $\begin{array}{l}\text { Reactor } \\
\text { wall } \\
\text { (HZ-007) }\end{array}$ & Cracking & $\begin{array}{l}\text { Subjected to impact } \\
\text { to crack }\end{array}$ & $\begin{array}{l}\text { Cannot create a vacuum } \\
\text { inside the reactor }\end{array}$ & No producing & 3 & 0.00004 & Yes & $\begin{array}{l}\text { Value of vacuum } \\
\text { detection system } \\
\text { established }\end{array}$ \\
\hline $\begin{array}{l}\text { Cold } \\
\text { junction } \\
\text { compensati } \\
\text { on box } \\
(\mathrm{HZ}-008) \\
\end{array}$ & Over heat & $\begin{array}{l}\text { 1.Ohmic contact is } \\
\text { too large } \\
\text { 2.Insufficient bolt } \\
\text { torque }\end{array}$ & $\begin{array}{l}\text { 1.Process stops } \\
\text { functioning andwarning } \\
\text { lighting } \\
\text { 2.Scorch smell }\end{array}$ & $\begin{array}{l}\text { 1. Overheat and catch fire } \\
\text { 2.Defective products } \\
\text { 3.VESDA system action }\end{array}$ & 3 & 0.005 & & $\begin{array}{l}\text { 1.System circuit } \\
\text { breaker protection } \\
\text { and warning light } \\
\text { 2. VESDA system } \\
\text { established }\end{array}$ \\
\hline $\begin{array}{l}\text { Thermocou } \\
\text { ple } \\
\text { (HZ-009) }\end{array}$ & $\begin{array}{l}\text { Unable to } \\
\text { measure } \\
\text { temperature }\end{array}$ & $\begin{array}{l}\text { 1.thermocouplebur } \\
\text { ned } \\
\text { 2.Circuit contacts } \\
\text { off }\end{array}$ & $\begin{array}{l}\text { 1.Process stops } \\
\text { functioning andwarning } \\
\text { lighting } \\
\text { 2.Scorch smell }\end{array}$ & $\begin{array}{l}\text { 1.Defective products } \\
\text { 2. No producing }\end{array}$ & 3 & 0.002 & Yes & $\begin{array}{l}\text { 1.Digital } \\
\text { temperature } \\
\text { control system } \\
\text { established } \\
\text { 2. VESDA system } \\
\text { established }\end{array}$ \\
\hline $\begin{array}{l}\text { Quartz tube } \\
\text { (HZ-010) }\end{array}$ & Cracking & $\begin{array}{l}\text { 1.Subjected to } \\
\text { impact to crack } \\
\text { 2.Temperature } \\
\text { changeto crack }\end{array}$ & $\begin{array}{l}\text { 1. Machine internal gas } \\
\text { leak detection system } \\
\text { operation. } \\
\text { 2. Process stops } \\
\text { functioning }\end{array}$ & $\begin{array}{l}\text { 1.Defective products } \\
\text { 2.ERT action }\end{array}$ & 4 & 0.00008 & Yes & $\begin{array}{l}\text { 1. Machine } \\
\text { internal gas leak } \\
\text { detection system } \\
\text { established. } \\
\text { 2. The reaction } \\
\text { gases linked and } \\
\text { stopped supply }\end{array}$ \\
\hline
\end{tabular}




\begin{tabular}{|c|c|c|c|c|c|c|c|c|}
\hline $\begin{array}{l}\text { Fan unit for } \\
\text { fast ramp } \\
\text { down } \\
(\text { HZ-011) }\end{array}$ & $\begin{array}{l}\text { The control } \\
\text { circuit } \\
\text { board or fan } \\
\text { failure }\end{array}$ & $\begin{array}{l}\text { 1.Electronic } \\
\text { Components } \\
\text { burned } \\
\text { 2.Open or short } \\
\text { circuit }\end{array}$ & Cooldown time increased & $\begin{array}{l}\text { Each batch process time becomes } \\
\text { longer }\end{array}$ & 1 & 0.01 & Yes & $\begin{array}{l}\text { 1.Digital } \\
\text { temperature } \\
\text { control system } \\
\text { established }\end{array}$ \\
\hline \multicolumn{9}{|c|}{$\begin{array}{l}\text { Explanation: } \\
\text { 1. The likelihood were derived from the supplier commercial machine, A-412 in this study.The heating element failure ratestatistics of real plant was consistent with the } \\
\text { original maintenance manual(ASM, 2013). } \\
\text { 2. Severitybased on SEMI-S10 was divided into five risk levels: thehighestisfive, and the lowest is one. } \\
\text { 3. Remarks or description was supplemented by protective equipment provided both programs and possible options, for thereaders'reference. }\end{array}$} \\
\hline
\end{tabular}

